\title{
UNIVERSITYOF BIRMINGHAM

\section{Seasonality of Holocene hydroclimate in the Eastern Mediterranean reconstructed using the oxygen isotope composition of carbonates and diatoms from Lake Nar, central Turkey}

\author{
Dean, Jonathan R.; Eastwood, Warren
}

DOI:

10.1177/0959683617721326

License:

None: All rights reserved

Document Version

Peer reviewed version

Citation for published version (Harvard):

Dean, JR \& Eastwood, W 2017, 'Seasonality of Holocene hydroclimate in the Eastern Mediterranean

reconstructed using the oxygen isotope composition of carbonates and diatoms from Lake Nar, central Turkey', The Holocene. https://doi.org/10.1177/0959683617721326

Link to publication on Research at Birmingham portal

Publisher Rights Statement:

(c) Sage 2017 .

Final Version of Record published as above.

\begin{abstract}
General rights
Unless a licence is specified above, all rights (including copyright and moral rights) in this document are retained by the authors and/or the copyright holders. The express permission of the copyright holder must be obtained for any use of this material other than for purposes
\end{abstract} permitted by law.

- Users may freely distribute the URL that is used to identify this publication.

- Users may download and/or print one copy of the publication from the University of Birmingham research portal for the purpose of private study or non-commercial research.

- User may use extracts from the document in line with the concept of 'fair dealing' under the Copyright, Designs and Patents Act 1988 (?)

- Users may not further distribute the material nor use it for the purposes of commercial gain.

Where a licence is displayed above, please note the terms and conditions of the licence govern your use of this document.

When citing, please reference the published version.

Take down policy

While the University of Birmingham exercises care and attention in making items available there are rare occasions when an item has been uploaded in error or has been deemed to be commercially or otherwise sensitive.

If you believe that this is the case for this document, please contact UBIRA@lists.bham.ac.uk providing details and we will remove access to the work immediately and investigate. 
Dean, J.R., Jones, M.D., Leng, M.J., Metcalfe, S.E., Sloane, H.J., Eastwood, W.J., Roberts, C.N., Seasonality of Holocene hydroclimate in the Eastern Mediterranean reconstructed using the oxygen isotope composition of carbonates and diatoms from Lake Nar, central Turkey. The Holocene DOI: https://doi.org/10.1177/0959683617721326

Copyright (C) 2017 The authors. Reprinted by permission of SAGE Publications. 
1 Seasonality of Holocene hydroclimate in the Eastern Mediterranean reconstructed

2 using the oxygen isotope composition of carbonates and diatoms from Lake Nar,

3 central Turkey

4

5 Jonathan R Dean ${ }^{1,2,3,4 *}$, Matthew D Jones ${ }^{2,3}$, Melanie J Leng ${ }^{1,3}$, Sarah E Metcalfe ${ }^{2,3}$,

6 Hilary J Sloane ${ }^{1}$, Warren J Eastwood ${ }^{5}$ and C Neil Roberts ${ }^{6}$

7

$8 \quad{ }^{1}$ NERC Isotope Geosciences Facilities, British Geological Survey, UK

$9 \quad{ }^{2}$ School of Geography, University of Nottingham, UK

$10{ }^{3}$ Centre for Environmental Geochemistry, University of Nottingham, UK

$11{ }^{4}$ School of Environmental Sciences, University of Hull, UK

$12{ }^{5}$ School of Geography, Earth and Environmental Sciences, University of Birmingham,

$13 U K$

$14{ }^{6}$ School of Geography, Earth and Environmental Sciences, University of Plymouth, UK

15

$16 *$ Corresponding author Jonathan R Dean

$17 \quad$ j.dean2@hull.ac.uk

18 School of Environmental Sciences, University of Hull, Hull HU6 7RX UK

19

20 


\section{Abstract}

23 A positive shift in the oxygen isotope composition $\left(\delta^{18} \mathrm{O}\right)$ of lake carbonates in the

24 Eastern Mediterranean from the early to late Holocene is usually interpreted as a change to drier (reduced P/E) conditions. However, it has also been suggested that changes in

26 the seasonality of precipitation could explain these trends. Here, Holocene records of

$27 \delta^{18} \mathrm{O}$ from both carbonates and diatom silica, from Lake Nar in central Turkey, provide

28 insights into palaeoseasonality. We show how $\Delta \delta^{18} \mathrm{O}_{\text {lakewater }}$ (the difference between

29 spring and summer reconstructed $\delta^{18} \mathrm{O}_{\text {lakewater }}$ ) was minimal in the early Holocene and

30 for most of the last millennium, but was greater at other times. For example, between

$31 \sim 4,100-1,600$ years BP we suggest that increased $\Delta \delta^{18} \mathrm{O}_{\text {lakewater }}$ could have been the

32 result of relatively more spring/summer evaporation, amplified by a decline in lake

33 level. In terms of change in annual mean $\delta^{18} \mathrm{O}$, isotope mass balance modelling shows

34 that this can be influenced by changes in seasonal P/E as well as inter-annual P/E, but

35 lake level falls inferred from other proxies confirm there was a mid Holocene transition

36 to drier climatic conditions in central Turkey.

\section{Keywords}

38 Oxygen isotopes; Eastern Mediterranean; lake sediment; Mid Holocene Transition; palaeoseasonality; Turkey 


\section{$40 \quad 1 \quad$ Introduction}

41

42 Understanding the detail of hydrological variability over multiple timescales is

43 important in regions such as the Eastern Mediterranean where water stress is increasing

44 (Issar and Adar, 2010) and where management of water supplies under a changing

45 climate is essential (e.g. Kelley et al., 2015). Water availability issues have potentially

46 been critical for societies in the region for millennia (e.g. Weiss et al., 1993) and an

47 understanding of both changes in mean state and seasonality are required (Rohling,

48 2016). Many studies from the region have shown a shift in the mid Holocene to higher

oxygen isotope ratios of lake carbonates $\left(\delta^{18} \mathrm{O}_{\text {carbonate }}\right)$ (Roberts et al., 2008). These are

usually interpreted as responding to changes in the balance between precipitation and evaporation (P/E) (Jones and Roberts, 2008), thus showing a mid Holocene transition

52 from a wetter early Holocene, with relatively more precipitation, to a drier late

53 Holocene, where evaporation losses were relatively increased. However, the extent to

54 which there were shifts in the seasonality of precipitation in the Holocene, and the

55 degree to which these would have affected $\delta^{18} \mathrm{O}_{\text {carbonate, }}$ remains an unresolved issue in

56 Eastern Mediterranean Holocene palaeoclimatology. Stevens et al. (2001, 2006)

57 suggested that a change from winter- to spring-dominated precipitation was potentially

58 a driver of the increasing $\delta^{18} \mathrm{O}_{\text {carbonate }}$ trend in the mid Holocene, based on analysis of

59 the sediments of Lakes Zeribar and Mirabad in Iran. Other authors, using pollen and 
60 microcharcoal records, have also argued that there were shifts in the seasonality of

61 precipitation in the region through the Holocene (e.g. Djamali et al., 2010; Turner et al.,

62 2010; Peyron et al., 2011).

63

64 Seasonality change analysis requires proxies that are sensitive to different seasons. Dean

65 et al. (2013) showed that comparing $\delta^{18} \mathrm{O}$ from endogenic carbonates and diatoms at

66 Nar Gölü (Gölü = lake in Turkish) in central Anatolia can provide insights into

67 seasonality as they formed/grew at different times of the year. Such records, combining

$68 \delta^{18} \mathrm{O}$ from diatoms and carbonates in the same core, remain rare. Here, we present a

$\delta^{18} \mathrm{O}_{\text {carbonate }}$ vs. $\delta^{18} \mathrm{O}_{\text {diatom }}$ record from Nar Gölü for the entire Holocene, developing a

rigorous methodology for diatom isotope data correction, coupled with an isotope mass

balance model, to investigate how and why intra-annual variability (seasonality) of

$72 \quad \delta^{18} \mathrm{O}_{\text {lakewater }}$ changed over time.

73

74

\section{Site description and core material}

75

Nar Gölü (38²0’24’’N, 34²7’23'’'E; 1363 m.a.s.l.; Figure 1) is a maar lake, 0.6 km²

77 in area and $>20 \mathrm{~m}$ deep, located in the Cappadocia region of central Turkey. The climate of the region is continental Mediterranean (Kutiel and Türkeş, 2005), with precipitation at a nearby meteorological station in Niğde, $45 \mathrm{~km}$ from Nar Gölü, 
averaging $339 \mathrm{~mm}$ per year and peaking in April and May. The crater geology is dominated by basalt and ignimbrite (Gevrek and Kazanc1, 2000). The limnology and contemporary sedimentation patterns are described in detail in Dean et al. (2015a), but in summary endogenic carbonate precipitation in the lake surface waters is weighted towards the early summer (end of June/beginning of July), whereas diatom production is weighted towards the spring (end of March/beginning of April). There was $~ 1.6 \%$ intra-annual variability in $\delta^{18} \mathrm{O}_{\text {lakewater }}$ through our June 2011 to July 2012 monitoring period (the period for which we have samples through all seasons), $\sim 0.5 \%$ of which occurred between the estimated time of peak diatom growth in spring 2012 and carbonate formation in the early summer 2012 (Figure 2). We believe the timing of diatom growth and carbonate precipitation is likely to have stayed roughly the same through the Holocene. As we show in section $4, \delta^{18} \mathrm{O}_{\text {lakewater }}$ reconstructed for the time of diatom growth is almost always lower than $\delta^{18} \mathrm{O}_{\text {lakewater }}$ reconstructed for the time of carbonate precipitation, and this would not be the case if diatom growth was weighted to the summer or early autumn (Figure 2). Indeed, previous work showed there were three planktonic/facultative planktonic ‘bloom' taxa common in the Nar Gölü diatom record over the last 1,700 years that are likely to have been spring blooming: Synedra acus, Nitzschia palaeacea and Cyclotella meneghiniana (Woodbridge and Roberts 2011). These taxa were also the dominant 'bloom' diatoms in the early Holocene (11,700-6,500 years BP) and it is reasonable to assume that their seasonal ecology was 
100 the same at that time as during the late Holocene. The only additional early Holocene

101 bloom diatom is Aulacoseira ambigua, but this is only important in two samples

102 (11,657 and 11,403 years BP). In the section from 4,400-3,900 years BP it is possible

103

104

105

106

107

108

109

110

111

112

113

114

115

116

117

118

119 that Nitzschia palaea was a bloom taxon and it is likely to have been spring blooming like $N$. palaeacea. The majority of carbonate is always likely to have precipitated in the early summer in response to increasing evaporation (Dean et al., 2015a).

Figure 1

Figure 2

There have been a number of previous palaeolimnological investigations of the Nar Gölü sediments (e.g. Jones et al., 2006; England et al., 2008; Woodbridge and Roberts, 2010). Here we combine data from the original core sequence taken in $2001 / 2$ (NAR01/02) with new data from a longer core sequence taken in 2010 (Roberts et al., 2016). The chronology of the NAR10 core was constructed by combining varve counting and U-Th dates (Dean et al., 2015b).

\section{$3 \quad$ Methods}




\subsection{Isotope sample preparation and mass spectrometry}

121

$122 \delta^{18} \mathrm{O}_{\text {carbonate }}$ data were produced using classic vacuum techniques and an Optima dual123 inlet mass spectrometer, as described in detail in Dean et al. (2015b). Specifically, the 124 carbonate analysed for isotopes from the Nar Gölü record was calcite and aragonite, as 125 detailed in Dean et al. (2015b). Data are given as \%o deviations from VPDB and 126 analytical reproducibility was $0.1 \%$ for $\delta^{18} \mathrm{O}$ and $\delta^{13} \mathrm{C}$.

127

128 Samples for $\delta^{18} \mathrm{O}_{\text {diatom }}$ analysis need to be as free as possible of non-diatom material since the analytical methods used will liberate oxygen from these other components of the sediment, such as carbonate and detrital silicates. Samples were therefore processed using techniques similar to those of Morley et al. (2004), with the use of hydrogen peroxide, nitric acid (to help remove organics; Tyler et al., 2007), hydrochloric acid, differential settling, sieving at $10 \mu \mathrm{m}$ and heavy liquid separation stages. $\delta^{18} \mathrm{O}_{\text {diatom }}$ analysis was carried out on cleaned diatom samples using the stepwise fluorination technique and a Thermo Finnigan MAT 253 at the NERC Isotope Geosciences Facilities. The method is described in Leng and Sloane (2008) and has been verified through an inter-laboratory comparison exercise (Chapligin et al., 2011). The data are presented as \%o deviations from VSMOW and analytical reproducibility was $0.3 \%$. 
140 Diatom isotope samples prepared from $\sim 8,800-7,900$ and $\sim 4,000-2,350$ years BP had 141 insufficient diatom silica for analysis, although there were still diatoms growing in the

142 lake at this time (Roberts et al., 2016).

143

\subsection{Correction of diatom isotope data}

The samples from Nar Gölü still contained residual detrital silicates after the preparation described above due to a lack of density contrast between the detrital silicates and the diatoms, which reduced the efficacy of heavy liquid separation (Dean et al., 2013). A correction was, therefore, applied to account for the impact of detrital silicates on $\delta^{18} \mathrm{O}$ (Mackay et al. 2011):

154 where $\delta^{18} \mathrm{O}_{\text {diatom }}$ is the original isotope value of the prepared diatom sample, $\%_{\text {contamination }}$ 155 and $\%_{\text {diatom }}$ are calculated using Eq. 2 (details below) and $\delta^{18} \mathrm{O}_{\text {contamination }}$ is the isotope 156 value of contamination.

157

158 A number of modifications were made to the methodology for the contamination 159 correction of $\delta^{18} \mathrm{O}_{\text {diatom }}$ samples that was previously used for Nar Gölü sediments (Dean 
et al., 2013) to make it more robust. For element concentration data, here we use an XRF (Panalytical epsilon 3 XL) rather than an Energy-Dispersive X-ray Spectroscopy (EDS) probe, allowing for more precise measurements of aluminium concentrations (a good marker for the amount of detrital silicates present (Mackay et al., 2011)), with an analytical reproducibility of $0.03 \%$. The XRF was set up to quantify the proportions of $\mathrm{Na}, \mathrm{Mg}, \mathrm{Al}, \mathrm{Si}, \mathrm{P}, \mathrm{S}, \mathrm{K}, \mathrm{Ca}, \mathrm{T}, \mathrm{Mn}$ and Fe using the Panalytical Omnian program. Instead of calculating the $\delta^{18} \mathrm{O}$ of contamination through the intercept of the $\delta^{18} \mathrm{O}_{\text {diatom }}$ vs. contamination plot, nine turbidites from along the NAR10 core were prepared and run in the same way as the diatom isotope samples. They had a mean $\delta^{18} \mathrm{O}$ value of $16.0 \%$ ( $( \pm 1.0 \%)$, which is within uncertainty of the value of $16.5 \%$ estimated in Dean et al. (2013) from NAR01/02. It is likely that \% contamination was overestimated in Dean et al. (2013) because some minerogenic contamination will be removed by the first fluorination stage before $\delta^{18} \mathrm{O}$ is measured (Swann and Leng, 2009) and diatom frustules can incorporate aluminium, so $\mathrm{Al}_{2} \mathrm{O}_{3} \%$ in the samples does not only reflect minerogenic contamination (Beck et al., 2002; Koning et al., 2007; Swann, 2010; Ren et al., 2013). To investigate the latter effect, Scanning Electron Microscopy (SEM) was used to identify individual clean diatoms (i.e. with no detrital silicates visible at all) and the $\mathrm{Al}_{2} \mathrm{O}_{3}$ wt $\%$ of the individual diatoms was measured by EDS, averaging $1.0 \% \pm 0.4$ $(1 \sigma)$ for the individual diatoms measured across 16 samples. This suggests that there is a significant amount of diatom-bound aluminium, so a correction factor was applied to 
180 account for this. Based on the average $\mathrm{Al}_{2} \mathrm{O}_{3}$ value of the turbidite layers throughout the

181 core sequence that were prepared and run as $\delta^{18} \mathrm{O}_{\text {diatom }}$ samples, $14.56 \% \mathrm{Al}_{2} \mathrm{O}_{3}$

182 represents $100 \%$ contamination (i.e. all detrital silicates, no diatoms). $1 \% \mathrm{Al}_{2} \mathrm{O}_{3}$

183 represents $0 \%$ contamination. Thus, there is an equation, derived from Figure SI-1, that

184 can be used to calculate the new $\%$ contamination values for our samples:

185

$\%_{\text {contamination }}=\left(7.3746 \mathrm{x}\right.$ sample $\left._{\mathrm{Al}}\right)-7.3746$

187

188

where sample $\mathrm{Al}_{\mathrm{l}}$ is the measured $\mathrm{Al}_{2} \mathrm{O}_{3}$ concentration in each sample analysed for

$\delta^{18} \mathrm{O}_{\text {diatom. }}$ Eq. 2 was used to calculate the $\%_{\text {contamination values for Eq. } 1 \text {. This modified }}$ methodology was used on the new samples from NAR10, as well as to recalculate the corrections to the NAR01/02 data presented in Dean et al. (2013). Henceforth, $\delta^{18} \mathrm{O}_{\text {diatom }}$ refers to the corrected $\delta^{18} \mathrm{O}_{\text {diatom }}$ data.

193

194 Uncertainties from individual components of the correction are outlined in Table 1 and

195 were combined to calculate the overall uncertainty associated with the correction.

196 Uncertainties are reduced compared to those reported in Dean et al. (2013) because of

197 the improved methodology. Figure SI-2 shows the original corrected NAR01/02 data published in Dean et al. (2013) compared to re-calculated values used in this paper. 
al. (2013) had sufficient material remaining for re-analysis by XRF (so data are now excluded), the general trends are very similar, with periods of lower $\delta^{18} \mathrm{O}$ particularly at $1,450,1,250$ and 120 years BP. The overall similarities in trends mean that the interpretations of Dean et al. (2013) are still valid, although for consistency in this paper we present the re-analysed NAR01/02 data along with the NAR10 data.

205

\subsection{Calculating $\delta^{18}$ Olakewater}

207

208

To allow for direct comparison of the $\delta^{18} \mathrm{O}$ data from carbonates and diatoms, we

209 estimate $\delta^{18} \mathrm{O}_{\text {lakewater }}$ at the time of carbonate precipitation and diatom growth using the

210 calcite (Kim and O'Neil, 1997), aragonite (Grossman and Ku, 1986) and diatom

214

215

$\delta^{18} \mathrm{O}_{\text {lakewater }}=\delta^{18} \mathrm{O}_{\text {aragonite }}-(\mathrm{T}-19.7) /-4.34$

216

217

$\delta^{18} \mathrm{O}_{\text {lakewater }}=\delta^{18} \mathrm{O}_{\text {diatom }}-(\mathrm{T}-245) /-6.25$ 
219 where $\delta^{18} \mathrm{O}_{\text {lakewater }}$ and $\delta^{18} \mathrm{O}_{\text {diatom }}$ are expressed on the VSMOW scale, $\delta^{18} \mathrm{O}_{\text {calcite }}$ and

$220 \delta^{18} \mathrm{O}_{\text {aragonite }}$ against VPDB and $\mathrm{T}$ in ${ }^{\circ} \mathrm{C}$. We use a temperature range of +15 to $+20^{\circ} \mathrm{C}$ for

221 the time of carbonate precipitation and +5 to $+10^{\circ} \mathrm{C}$ for the time of diatom growth,

222 justified by our measurements of seasonal lake waters from 2011-2013 (Figure 2 and

223 Eastwood et al., unpublished data). The temperature range for the time of diatom growth

224 has been reduced from that used in Dean et al. (2013), where we estimated +5 to $+15^{\circ} \mathrm{C}$,

225 because of our increased knowledge of intra-annual epilimnion temperature variability

226 with the additional years of temperature logging data from Nar Gölü. While we

227 recognise that there will have been changes in temperature during the Holocene, these

228 changes are likely to have been only a few degrees centigrade (see references in section

229 5.1), smaller than the ranges of $5^{\circ} \mathrm{C}$ given for the times of diatom growth and carbonate 230 precipitation.

231

232

3.4 Lake isotope mass balance models

233

234 To examine further the changes in hydroclimate seasonality and how this would be

235 recorded in the seasonality of the lake $\delta^{18} \mathrm{O}$ system, we use an isotope mass balance 236 model, employing the equations outlined in Jones and Imbers (2010) and Jones et al. 237 (2016), and fully explained in the Supplementary Information. The equations are based on monthly time steps to allow investigations of changing intra-annual $\delta^{18} \mathrm{O}_{\text {lakewater }}$ 
239 variability under different climatic states that have been identified from the isotope data:

240 for the present day (Modern), the Mid Holocene (here meaning from approximately

2416,000 to 1,600 years BP) and the Early Holocene.

242

243 For the present day, average monthly values of temperature (average [Tav], minimum

$244[$ Tmin] and maximum [Tmax]), total precipitation (P) and snowfall between 2005 and

2452011 (only until 2010 for snowfall) from the meteorological station at Niğde were used

246 to drive a model of modern conditions in a lake with the same volume $\left(\sim 7,500,000 \mathrm{~m}^{3}\right)$

247 and lake area $\left(556,500 \mathrm{~m}^{2}\right)$ as Nar Gölü (Table 2 and Supplementary Information).

248

249 In this modern lake setting, annual average $\delta^{18} \mathrm{O}_{\text {lakewater }}$ in the model is $0.59 \%$ with a

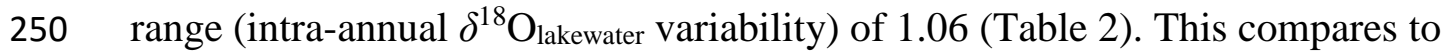

251 measured summer values at Nar Gölü of between -1.9 and $-0.2 \%$ or the same period

252 (2005-2011), and an intra-annual range of $\sim 1.6 \%$ (Dean et al., 2015a). The difference

253 between the measured data and the model are due to a number of factors. Firstly, the

254 model is for a lake in Niğde, the location of the nearest meteorological station, not for

255 Nar Gölü. This will affect the precipitation and evaporation components of the model,

256 and therefore the parameterisation of surface and groundwater inflow and outflow,

257 which have narrow windows for a given lake in a given location (Jones et al., 2016).

258 Nar Gölü is also stratified, adding a level of complexity to the isotope hydrology not 
259 included in the model. However, the model in the Modern scenario has mean and intra260 annual $\delta^{18} \mathrm{O}$ values in the same order as Nar Gölü, and is used here not to recreate 261 conditions at Nar Gölü precisely, but to inform our discussion of why $\delta^{18} \mathrm{O}$ may change 262 in time. As such, the model is deliberately simple, and appropriate. Inputs to the model 263 for the palaeoclimate scenarios are based on our best understanding of regional 264 temperature and precipitation changes from the literature (see discussions below).

\section{Results}

267

268 Figure 3 shows $\delta^{18} \mathrm{O}_{\text {carbonate }}$ and $\delta^{18} \mathrm{O}_{\text {diatom }}$ plotted against depth. There are gaps in both 269 the $\delta^{18} \mathrm{O}_{\text {carbonate }}$ record, where interpretation of $\delta^{18} \mathrm{O}_{\text {carbonate }}$ values is complicated by 270 dolomite precipitation (Dean et al., 2015b), and the $\delta^{18} \mathrm{O}_{\text {diatom }}$ record, because there was 271 not enough diatom silica for isotope analysis and/or samples were too contaminated

272 (with detrital silicates and at times additionally with dolomite), even after cleaning, to 273 run. Because of issues with the chronology discussed elsewhere (Dean et al., 2015b; 274 Roberts et al., 2016), the data between 1034-1161 cm are not plotted on Figure 4. 275

\section{$276 \quad$ Figure 3}


280 The overall trends in $\delta^{18} \mathrm{O}_{\text {carbonate }}$ and $\delta^{18} \mathrm{O}_{\text {diatom }}$ are similar. Both have lower values 281 towards the bottom of the core in the period likely to be at the time of the Bølling282 Allerød, higher values at the time of the Younger Dryas, and lower values in the early 283 Holocene (Figure 4). Both $\delta^{18} \mathrm{O}_{\text {diatom }}$ and $\delta^{18} \mathrm{O}_{\text {carbonate }}$ increase at $~ 7,500$ years BP to 284 higher values (by 4\%o VSMOW for $\delta^{18} \mathrm{O}_{\text {diatom }}$ and $\sim 5 \%$ VPDB for $\delta^{18} \mathrm{O}_{\text {carbonate). }}$ ).

285 However, a major difference is that while there is another increase in $\delta^{18} \mathrm{O}_{\text {carbonate }}(>2 \%$ o VPDB) 4,100 years BP, ending with peak Holocene values that are maintained until $\sim 1,600$ years BP, there is no corresponding second increase in $\delta^{18} \mathrm{O}_{\text {diatom }}$ values. Where data are available, $\delta^{18} \mathrm{O}_{\text {diatom }}$ values are relatively stable, at c. $+37 \%$ VSMOW for the period 7,000 to 1,600 years BP after rising from early Holocene values of c. $+33 \%$. Both $\delta^{18} \mathrm{O}_{\text {carbonate }}$ and $\delta^{18} \mathrm{O}_{\text {diatom }}$ decline dramatically at $\sim 1,600$ years BP for $\sim 400$ years, before returning to higher values for most of the last 1,000 years.

292

293 Figure 4 also shows $\delta^{18} \mathrm{O}_{\text {lakewater }}$ estimated for the times of diatom growth and carbonate 294 precipitation. Because late glacial temperatures are not well known, we only use the 295 palaeotemperature equations to reconstruct $\delta^{18} \mathrm{O}_{\text {lakewater }}$ for the Holocene, during which 296 annual average temperatures probably only changed by a few degrees in the region (e.g. 297 Emeis et al., 2000). The shaded areas on Figure 4C combine maximum and minimum

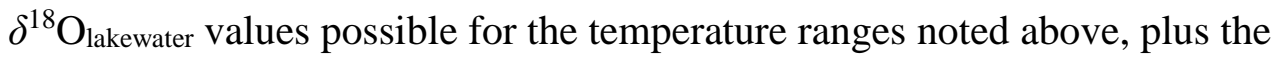


299 uncertainties associated with the $\delta^{18} \mathrm{O}_{\text {diatom }}$ contamination correction. $\delta^{18} \mathrm{O}_{\text {lakewater }}$ at the 300 time of diatom growth increased from c. $-5 \%$ in the early Holocene to c. $-1 \%$ in the mid 301 Holocene, before falling to c. $-15 \%$ 1,600-1,200 years BP and then returning to higher 302 values (c. -2 to $-3 \%$ ) for the last 1,000 years. $\delta^{18} \mathrm{O}_{\text {lakewater }}$ at the time of carbonate precipitation increased from c. $-3 \%$ in the early Holocene to c. $+1 \%$ \% $\sim 6,600$ years BP and to c. $+3 \%$ by $\sim 4,000$ years BP, before falling to c. $-4 \%$ 1, $600-1,200$ years BP and then increasing to c. $-1 \%$ for the last 1,000 years.

306

$307 \Delta \delta^{18} \mathrm{O}_{\text {lakewater }}$, the difference between $\delta^{18} \mathrm{O}_{\text {lakewater }}$ at the time of carbonate precipitation compared to the time of diatom growth, was only $\sim 1 \%$ in the early Holocene. It then increased to $\sim 4 \%$ for much of the time from $\sim 4,100$ to 1,600 years BP, as $\delta^{18} \mathrm{O}_{\text {lakewater }}$ at 310 the time of carbonate precipitation increased 4,100 years BP, but $\delta^{18} \mathrm{O}_{\text {lakewater }}$ at the time of diatom growth did not (Figure 4C). Then, 1,600-1,200 years BP, because the fall in $\delta^{18} \mathrm{O}_{\text {diatom }}$ is much greater than the fall in $\delta^{18} \mathrm{O}_{\text {carbonate, }} \Delta \delta^{18} \mathrm{O}_{\text {lakewater values are }}>10 \%$.

313 For the last 1,000 years, $\Delta \delta^{18} \mathrm{O}_{\text {lakewater }}$ declined to levels more similar to the early

314 Holocene. Limited variability in recent times is also shown in our monitoring data, with 315 only a $0.5 \%$ difference in our lakewater samples between April and July in 2012 316 (Figure 2) and a 0.7\%o difference seen between April and August 2002 (Jones et al., 317 2005). 


\section{Discussion}

321 From the isotope data, there appear to be three key lake states: 1 . limited difference

322 between $\delta^{18} \mathrm{O}_{\text {lakewater }}$ at the times of diatom growth and carbonate precipitation, i.e.

$323 \Delta \delta^{18} \mathrm{O}_{\text {lakewater }} \sim 1 \%$ (during the early Holocene and last 1,000 years); 2 . intermediate

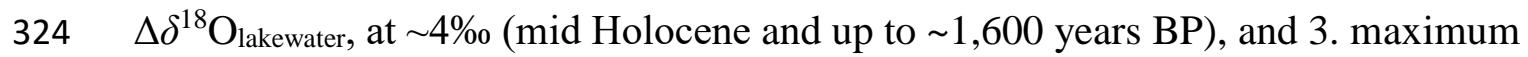

$325 \Delta \delta^{18} \mathrm{O}_{\text {lakewater, at }} \sim 10 \%$ o $(\sim 1,600-1,200$ years BP $)$. We discuss these in turn. The

326 differences in resolution between the carbonate and diatom isotope data means that we

327 limit ourselves to comparing the long-term general trends in the data through the early

328 and mid Holocene.

329

\subsection{The early Holocene $(11,700$ to 6,500 years $B P)$}

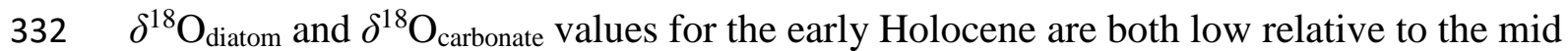
and late Holocene (Figure 4), which could indicate higher annual average P/E (i.e. effectively wetter conditions) in the early Holocene, as has been suggested by other studies (summarised in Roberts et al., 2008). Specifically, pollen data (Djamali et al., 2010; Kotthoff et al., 2008; Peyron et al., 2011; Peyron et al., 2017), microcharcoal data

337 (Wick et al., 2003; Turner et al., 2008; Vanniere et al., 2011), climate modelling results 
$339 \sim 160 \mathrm{~km}$ SW of Nar (Bar-Yosef Mayer et al., 2012; Lewis et al., 2017) have suggested

340 that the early Holocene in the Eastern Mediterranean region had wetter winters than

341 present, but with many of the studies suggesting drier springs and/or summers. Annual

342 average temperatures were several degrees cooler in the early Holocene compared to the

343 late Holocene, as reconstructed by alkenone-derived sea surface temperatures (Emeis et

344 al., 2000; Triantaphyllou et al., 2009) and speleothem fluid inclusions (McGarry et al.,

345 2004). However, the prominence of Pistacia in the pollen record from Nar Gölü

346 (Roberts et al., 2016) and from nearby Eski Acıgöl (Roberts et al., 2001; Woldring and

347 Bottema, 2003), between 11,000 and 8,000 years BP, suggests winters were milder than

348 today (Rossignol-Strick, 1999). Therefore, the inferred drops in annual temperature may

349 have been concentrated in the summer. There is, however, a gap in the $\delta^{18} \mathrm{O}_{\text {diatom }}$ record

350 between 8,800 and 7,900 years BP due to there being too little diatom silica for diatom

351 isotope measurements to be made. Intriguingly, this period coincides with a phase of

352 marked spring floods on the Çarşamba river in Anatolia (Boyer et al., 2006), which

353 would have been caused by enhanced spring snowmelt in its upper watershed in the

354 Taurus mountains. Despite the fact that spring and summer precipitation may have been

355 lower in the early Holocene than the present day, $\delta^{18} \mathrm{O}_{\text {carbonate }}$ is still lower in the early

356 Holocene and there is limited $\Delta \delta^{18} \mathrm{O}_{\text {lakewater. }}$ Presumably, the lower $\delta^{18} \mathrm{O}_{\text {carbonate }}$ and

357 limited $\Delta \delta^{18} \mathrm{O}_{\text {lakewater }}$ is due to relatively less summer evaporation of the lake waters

358 compared to the mid and late Holocene, which is to be expected if there were lower 
359 temperatures in the early Holocene spring/summer, as well as increased winter

360 precipitation. Our mass balance modelling allows us to refine our basic interpretation of 361 hydroclimate in the early Holocene.

362

363 In our early Holocene model, we have reduced the annual average temperature by $1{ }^{\circ} \mathrm{C}$, 364 as estimated from the studies cited above and as used in Jones et al. (2007); details in SI 365 Tables. Annual precipitation values are kept the same as the present day, but the 366 seasonal distribution has been shifted to more winter-dominated with no snow, as is 367 indicated by the literature discussed above. Under this scenario, average annual lake 368 water values are lower than the present day model $(-2.81 \%)$, and could be even more so 369 if annual-averaged precipitation was increased under the same P/E seasonality regime, 370 as seems possible (Roberts et al., 2008). This demonstrates that the seasonality of P/E, 371 in addition to the average annual conditions, is important in controlling inter-annual 372 changes in $\delta^{18} \mathrm{O}_{\text {lakewater. }}$

374 To investigate further the relative contributions of precipitation and temperature (linked 375 closely to evaporation in this model), an early Holocene scenario, using modern day 376 temperatures (as well as modern day annual-average precipitation levels again) and 377 changing only the seasonal distribution of precipitation, was also undertaken. Here

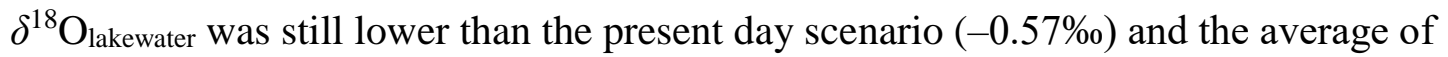


379 monthly P/E increases (Table 2). This result drives a difference in this model because 380 groundwater inflow and outflow are dependent on $\mathrm{P} / \mathrm{E}$, with additional groundwater

381 outflow required in the early Holocene compared to present day to balance the lake 382 system, and suggesting higher lake levels under early Holocene conditions. This 383 indicates that changing the seasonal distribution of $\mathrm{P} / \mathrm{E}$, irrespective of annual average 384 conditions, can lead to changes in both lake hydrology and lake isotope composition. It 385 highlights the need to be careful when suggesting that the early Holocene was 'wetter' 386 than the mid and late Holocene based solely on evidence from lake sediment isotopes, 387 as now it is clear that changes in the seasonality of $\mathrm{P} / \mathrm{E}$ have an impact on $\delta^{18} \mathrm{O}$, in part 388 due to changes in seasonal water balance as well as due to changes in $\delta^{18} \mathrm{O}$ of 389 precipitation (Table 2), as suggested by Stevens et al. $(2001,2006)$ for Lakes Zeribar 390 and Mirabad.

5.2 The mid Holocene ( 6,500 to $\sim 1,600$ years BP)

393

394 At Nar Gölü, a number of proxies respond to changes in lake level, usually driven by 395 changes in P/E, such as lithology (varved vs. non-varved), carbonate mineralogy (calcite 396 vs. aragonite and dolomite) (Dean et al., 2015b), the Sr-Ca elemental ratio and certain 397 diatom species (Roberts et al., 2016). These multiple proxies indicate that annual average $\mathrm{P} / \mathrm{E}$ was probably lower after $\sim 6,500$ years BP compared to the early Holocene. 
399 We know at Nar Gölü that lake level falls lead to more positive $\delta^{18} \mathrm{O}_{\text {carbonate }}$ (Dean et al., 400 2015a) and therefore a significant part of the $\delta^{18} \mathrm{O}$ trend in carbonates and diatoms to 401 higher values in the mid and late Holocene, compared to the early Holocene, is likely 402 related to a shift to drier conditions. Other influences on $\delta^{18} \mathrm{O}$, such as changes in the isotopic composition of the source of precipitation, amount effect or temperature, could not have accounted for the large size of the shift in both $\delta^{18} \mathrm{O}_{\text {carbonate }}$ and $\delta^{18} \mathrm{O}_{\text {diatom }}$ from the early to mid and late Holocene.

406

$407 \Delta \delta^{18} \mathrm{O}_{\text {lakewater }}$ does not initially increase in the mid Holocene because both $\delta^{18} \mathrm{O}_{\text {carbonate }}$ 408 and $\delta^{18} \mathrm{O}_{\text {diatom }}$ increase, but in the period $\sim 4,100$ to $\sim 1,600$ years BP $\delta^{18} \mathrm{O}_{\text {lakewater }}$ at the time of diatom growth is up to $\sim 4 \%$ lower than at the time of carbonate precipitation (Figure 4). Annual average precipitation must have been lower for most of the mid and late Holocene compared to the early Holocene (Jones et al., 2007). It is possible that a significant share of this precipitation decline occurred $\sim 7,500$ years BP, while at $\sim 4,100$ years BP there was a rise in summer evaporation but winter/spring precipitation levels did not change substantially. If that was the case, that would explain why both $\delta^{18} \mathrm{O}_{\text {diatom }}$

415 (responding more to winter/spring precipitation) and $\delta^{18} \mathrm{O}_{\text {carbonate }}$ (responding more to 416 summer evaporation) increased $\sim 7,500$ years BP but only $\delta^{18} \mathrm{O}_{\text {carbonate }}$ increased at

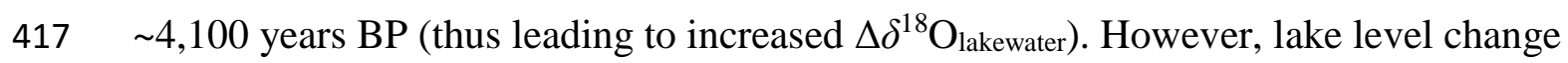
could account for some of this increased $\Delta \delta^{18} \mathrm{O}_{\text {lakewater. }} \Delta \delta^{18} \mathrm{O}_{\text {lakewater }}$ will be more 
419 sensitive to inputs and outputs when the lake level and volume were lower, with less of 420 a buffering effect than when the lake level is higher: this is a well-known phenomenon 421 in limnology (e.g. Leng and Anderson, 2003; Steinman et al., 2010).

422

423 To test this with the lake isotope mass balance model, two model conditions are set for 424 this period. In both, precipitation is reduced compared to the present day as multi-proxy 425 evidence from Nar Gölü (Dean et al., 2015b; Roberts et al., 2016) and elsewhere in the 426 region (Roberts et al., 2008) points to lower lake levels at this time. In the first Mid 427 Holocene scenario (MHi), temperatures are held the same as the present day, resulting

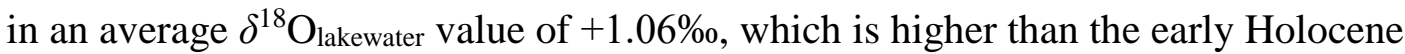
429 scenarios and thus supports our contention that some of the increase in $\delta^{18} \mathrm{O}$ could be 430 due to reduced annual precipitation. However, the range in the model is only $1.10 \%$ o 431 (Table 2), which is similar to the early Holocene model, despite the higher $\Delta \delta^{18} \mathrm{O}_{\text {lakewater }}$ seen in the data in the mid Holocene compared to the early Holocene. In the second Mid Holocene scenario (MHii), summer temperatures are raised to increase summer 434 evaporation such that $\mathrm{P} / \mathrm{E}$ seasonality is increased relative to $\mathrm{MHi}$. Average $\delta^{18} \mathrm{O}_{\text {lakewater }}$ 435 values become even more positive $(+2.00 \%)$ and the range increases $(1.22 \%$; Table 2$)$. 436 Further, a shift from a steady state lake with the same volume as the present day 437 scenario, in MHii conditions, to one with a $20 \%$ smaller volume, increases the intra- 
438

439

440

441

442

443

444

445

446

447

448

449

450

451

452

453

454

455

456

457

annual $\delta^{18} \mathrm{O}_{\text {lakewater }}$ range to $1.52 \%$, showing how a change to lower lake levels could account for some of the increase in $\Delta \delta^{18} \mathrm{O}_{\text {lakewater }}$ at this time (as discussed above).

To ensure steady state lakes under the mid Holocene climatic scenarios, the groundwater outflow constant has to be reduced (see Supplementary Information for model details). In the model, this is partly a function of P/E as more water entering the lake will push more of it out, however here it needs to be further reduced relative to present day to ensure a steady state lake, i.e. one where volume is not always increasing or decreasing at an annual time step. This suggests there are further controls on groundwater outflow that are not described by our simple model, possibly linked to lake volume and depth, with the lower lake levels of the mid Holocene also potentially contributing to reduced groundwater outflow at these times.

\subsubsection{Late Holocene (last 1,600 years)}

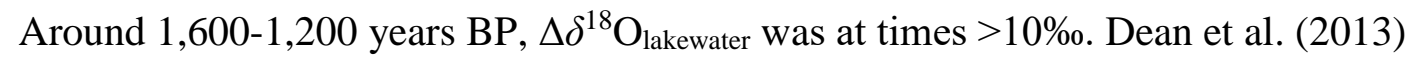
hypothesised that this was due to a seasonal freshwater lid of low $\delta^{18} \mathrm{O}$ snowmelt occurring at this time, in which the diatoms lived. To further investigate the sensitivity of the Nar Gölü system to snow volume, the modern lake isotope mass balance model was altered to have no snow, or double the amount of snow, keeping all other variables 
458 the same. This produced more positive or more negative annual average $\delta^{18} \mathrm{O}_{\text {lakewater }}$

459 values respectively, as would be expected by putting less or more negative $\delta^{18} \mathrm{O}$ water

460 into the system (Table 2). There is no impact on the range if these changes are made

461 into a well-mixed lake system as in the model, further suggesting that density

462 differences and stratification are probably important in explaining the $\Delta \delta^{18} \mathrm{O}_{\text {lakewater }}$

463 variability reconstructed down-core at Nar Gölü as proposed by Dean et al. (2013) for

464 this unusual period during the late Holocene.

465

$466 \quad 6 \quad$ Conclusions

467

468 The combination of two $\delta^{18} \mathrm{O}$ records, from diatoms and endogenic carbonate that

469 formed in Nar Gölü in central Turkey at different times of the year, helps to inform

470 discussion of palaeoseasonality. Our record indicates that there are three lake states

471 through the Holocene: the early Holocene and the last 1,000 years when there is limited

$472 \Delta \delta^{18} \mathrm{O}_{\text {lakewater, }}$, the mid Holocene and up to $\sim 1,600$ years BP when $\Delta \delta^{18} \mathrm{O}_{\text {lakewater was at }}$

473 times $\sim 4 \%$ and a short period $\sim 1,600-1,200$ years BP when $\Delta \delta^{18} \mathrm{O}_{\text {lakewater }}$ was $\sim 10 \%$.

474 Modelling results indicate that the increase in $\Delta \delta^{18} \mathrm{O}_{\text {lakewater }}$ from the early to the mid

475 Holocene could be related to changes in P/E seasonality, but a shift to lower lake levels

476 (and volumes) would have amplified the impact of any changes in P/E. Therefore,

477 while we have shown that using $\Delta \delta^{18} \mathrm{O}_{\text {lakewater }}$ to compare lake conditions at different 
478 times of the year can provide insights into seasonality, it is not a simple proxy for intra479 annual $\mathrm{P} / \mathrm{E}$ variability. In terms of inter-annual $\delta^{18} \mathrm{O}$ change, we suggest that lower $480 \delta^{18} \mathrm{O}_{\text {carbonate }}$ and $\delta^{18} \mathrm{O}_{\text {diatom }}$ values in the early Holocene compared to the present day 481 could partly be the result of changes in the seasonality of P/E. However, the multi-proxy 482 evidence available from Nar Gölü clearly points to a mid Holocene transition to lower 483 lake levels driven by annual-mean shifts to reduced P/E.

\section{Acknowledgments}

486

487

JRD was funded by NERC PhD studentship NE/I528477/1 (2010-2014). Diatom isotope work was funded by NIGFSC grant IP/1346/1112 to MDJ. Fieldwork was supported by National Geographic and British Institute at Ankara grants to CNR. All authors have contributed intellectually and approved the final version. We would like to thank those others who contributed to field work in 2010 at Nar Gölü: Samantha Allcock, Hakan Yiğitbaşığlu, Fabien Arnaud, Emmanuel Malet, Ersin Ateş, Çetin Şenkul, Gwyn Jones, Ryan Smith and Ceran Şekeryapan. George Swann is thanked for 494 his useful advice with the diatom isotope corrections. We thank Gianni Zanchetta and 495 an anonymous reviewer for helpful comments that improved the manuscript. A 496 Supplementary Information file and a data file are associated with the online version of 497 this paper. 


\section{References}

Bar-Yosef Mayer DE, Leng MJ, Aldridge DC, Arrowsmith C, Gumus BA and Sloane HJ (2012) Modern and early-middle Holocene shells of the freshwater mollusc

Beck L, Gehlen M, Flank AM, Van Bennekom AJ and Van Beusekom JEE (2002) The relationship between $\mathrm{Al}$ and $\mathrm{Si}$ in biogenic silica as determined by PIXE and XAS. Nuclear Instruments \& Methods in Physics Research Section B - Beam Interactions with Materials and Atoms 189: 180-184.

Boyer P, Roberts N and Baird D (2006) Holocene environment and settlement on the Çarşamba alluvial fan, South Central Turkey: Integrating Geoarchaeology and Archaeological Field Survey. GeoArchaeology 21: 675-699.

Brayshaw D, Hoskins B and Black E (2010) Some physical drivers of change in the winter storm tracks over the Atlantic and Mediterranean during the Holocene. Philosophical Transactions of the Royal Society of London 368: 5185-5223.

Chapligin B, Leng MJ, Webb E, Alexandre A, Dodd JP, Ijiri A, Lücke A, Shemesh A, Abelmann A, Herzschuh U, Longstaffec FJ, Meyer H, Moschen R, Okazaki Y, 
Rees NH, Sharp ZD, Sloane HJ, Sonzogni C, Swann GEA, Sylvestre F, Tyler JJ and Yam R (2011) Inter-laboratory comparison of oxygen isotope compositions from biogenic silica. Geochimica et Cosmochimica Acta 75: 7242-7256.

Crespin J, Sylvestre F, Alexandre A, Sonzogni C, Pailles C and Perga ME (2010) Reexamination of the temperature-dependent relationship between delta O18(diatoms) and delta O-18(lake water) and implications for paleoclimate inferences. Journal of Paleolimnolgy 44: 547-557.

Darling WG, Bath AH, Gibson JJ and Rozanski K (2006) Isotopes in Water. In: Leng MJ (ed) Isotopes in Palaeoenvironmental Research. Dordrecht: Springer.

Dean JR, Eastwood WJ, Roberts CN, Jones MD, Yigitbasioglu H, Allcock SL, Woodbridge J, Metcalfe SE and Leng MJ (2015a) Tracking the hydro-climatic signal from lake to sediment: a field study from central Turkey. Journal of Hydrology 529: 608-621.

Dean JR, Jones MD, Leng MJ, Noble SR, Metcalfe SE, Sloane HJ, Sahy D, Eastwood WJ and Roberts CN (2015b). Eastern Mediterranean hydroclimate over the late glacial and Holocene, reconstructed from the sediments of Nar lake, central Turkey, using stable isotopes and carbonate mineralogy. Quaternary Science Reviews 124: 162-174.

Dean JR, Jones MD, Leng MJ, Sloane HJ, Roberts CN, Woodbridge J, Swann GEA, Metcalfe SE, Eastwood WJ and Yigitbasioglu H (2013) Palaeo-seasonality of the 
last two millennia reconstructed from the oxygen isotope composition of carbonates and diatom silica from Nar Gölü, central Turkey. Quaternary Science Reviews 66: 35-44.

Djamali M, Akhani H, Andrieu-Ponel V, Braconnot P, Brewer S, de Beaulieu JL, Fleitmann D, Fleury J, Gasse F, Guibal F, Jackson ST, Lezine AM, Medail F, Ponel P, Roberts N and Stevens L (2010) Indian Summer Monsoon variations

Emeis KC, Struck U, Schulz HM, Rosenberg R, Bernasconi S, Erlenkeuser H, Sakamoto T and Martinez-Ruiz F (2000) Temperature and salinity variations of

Gevrek A and Kazanci N (2000) A Pleistocene, pyroclastic-poor maar from central Anatolia, Turkey: influence of a local fault on a phreatomagmatic eruption. Journal of Volcanology and Geothermal Research 95: 309-317 
558 Grossman EL and Ku TL (1986) Oxygen and carbon isotope fractionation in biogenic 559 aragonite - temperature effects. Chemical Geology 59: 59-74.

560 Issar A and Adar E (2010) Progressive development of water resources in the Middle 561 East for sustainable water supply in a period of climate change. Philosophical 562 Transactions of the Royal Society A - Mathematical Physical and Engineering Sciences 368: 5339-5350.

Jones MD, Cuthbert MO, Leng MJ, McGowan S, Mariethoz G, Arrowsmith C, Sloane HJ, Humphrey KK and Cross I (2016) Comparisions of observed and modelled lake $\delta^{18} \mathrm{O}$ variability. Quaternary Science Reviews 131: 329-340.

Jones MD and Imbers J (2010) Modelling Mediterranean lake isotope variability. Global and Planetary Change 71: 193-200.

Jones MD, Leng MJ, Roberts CN, Turkes M and Moyeed R (2005) A coupled calibration and modelling approach to the understanding of dry-land lake oxygen isotope records. Journal of Paleolimnology 34: 391-411.

572

Jones MD and Roberts CN (2008) Interpreting lake isotope records of Holocene 38.

575 Jones MD, Roberts CN and Leng MJ (2007) Quantifying climatic change through the last glacial-interglacial transition based on lake isotope palaeohydrology from central Turkey. Quaternary Research 67: 463-473. 
578 Jones MD, Roberts CN, Leng MJ and Türkeş M (2006) A high-resolution late Holocene 579 lake isotope record from Turkey and links to North Atlantic and monsoon climate. $580 \quad$ Geology 34: 361-364.

581 Kelley CP, Mohtadi S, Cane MA, Seager R and Kushnir Y (2015) Climate change in 582 the Fertile Crescent and implications of the recent Syrian drought. Proceedings of 583 the National Academy of Sciences 112: 3241-3246.

584 Kim ST and O'Neil JR (1997) Equilibrium and nonequilibrium oxygen isotope effects 585 in synthetic carbonates. Geochimica et Cosmochimica Acta 61: 3461-3475.

586 Koning E, Gehlen M, Flank AM, Calas G and Epping E (2007) Rapid post-mortem 587 incorporation of aluminum in diatom frustules: evidence from chemical and $588 \quad$ structural analyses. Marine Chemistry 106: 208-222.

589 Kotthoff U, Prodd J, Müller UC, Peyron O, Schmiedl G, Schulz H and Bordon A (2008)

590 Climate dynamics in the borderlands of the Aegean Sea during formation of 591 sapropel S1 deduced from a marine pollen record. Quaternary Science Reviews $592 \quad 27: 832-845$.

593 Kutiel H and Türkeş M (2005) New evidence for the role of the North Sea-Caspian 594 Pattern on the temperature and precipitation regimes in continental Central 595 Turkey. Geografiska Annaler Series A - Physical Geography 87A: 501-513. 596 Leng MJ and Anderson AJ (2003) Isotopic variation in modern lake waters from 597 western Greenland. The Holocene 13: 605-611.Leng MJ and Sloane HJ (2008). 

Quaternary Science 23: 313-319.

600

601

602

603

604

605

606

607

608

609

610

611

612

613

614

615

616

Lewis JP, Leng MJ, Dean JR, Marciniak A, Bar-Yosef Mayer DE and Wu X (2017) Early Holocene palaeoseasonality inferred from the stable isotope composition of Unio shells from Çatalhöyük, Turkey. Environmental Archaeology 1: 79-95.

Mackay AW, Swann GEA, Brewer TS, Leng MJ, Morley DW, Piotrowska N, Rioual P. and White D (2011) A reassessment of late glacial-Holocene diatom oxygen isotope record from Lake Baikal using a geochemical mass-balance approach. Journal of Quaternary Science 26: 627-634.

McGarry S, Bar-Matthews M, Matthews A, Vaks A, Schilman B and Ayalon A (2004) Constraints on hydrological and paleotemperature variations in the Eastern Mediterranean region in the last 140 ka given by the delta D values of speleothem fluid inclusions. Quaternary Science Reviews 23: 919-934.

Morley DW, Leng MJ, Mackay AW, Sloane HJ, Rioual P and Battarbee RW (2004) Cleaning of lake sediment samples for diatom oxygen isotope analysis. Journal of Paleolimnology 31: 391-401.

Peyron O, Combourieu-Nebout N, Brayshaw D, Goring S, Andrieu-Ponel V, Desprat S, Fletcher W, Gambin B, Ioakim C, Joannin S, Kotthoff U, Kouli K, Montade V, Pross J, Sadori L and Magny M (2017). Precipitation changes in the 
Mediterranean basin during the Holocene from terrestrial and marine pollen records: a model-data comparision. Climate of the Past 13: 249-265.

Peyron O, Goring S, Dormoy I, Kotthoff U, Pross J, De Beaulieu JL, DrescherSchneider R, Vanniere B and Magny M (2011) Holocene seasonality changes in the central Mediterranean region reconstructed from the pollen sequences of Lake Accesa (Italy) and Tenaghi Philippon (Greece). The Holocene 21: 131-146.

Ren H, Brunelle BG, Sigman DM and Robinson RS (2013) Diagenetic aluminum uptake into diatom frustules and the preservation of diatom-bound organic nitrogen. Marine Chemistry 155: 92-101.

Roberts CN, Allcock SL, Arnaud F, Dean JR, Eastwood WJ, Jones MD, Leng MJ, Metcalfe SE, Malet E, Woodbridge J and Yiğitbaşığlu H (2016) A tale of two lakes: a multi-proxy comparison of Late Glacial and Holocene environmental change in Cappadocia, Turkey. Journal of Quaternary Science 31: 348-362.

Roberts N, Jones MD, Benkaddour A, Eastwood WJ, Filippi ML, Frogley MR, Lamb HF, Leng MJ, Reed JM, Stein M, Stevens L, Valero-Garces B and Zanchetta G (2008) Stable isotope records of Late Quaternary climate and hydrology from Mediterranean lakes: the ISOMED synthesis. Quaternary Science Reviews 27: 2426-2441.

Roberts N, Reed JM, Leng MJ, Kuzucuoğlu C, Fontugne M, Bertaux J, Woldring H, Bottema S, Black S, Hunt, E and Karabiyikoglu M (2001) The tempo of Holocene 
climatic change in the eastern Mediterranean region: new high-resolution craterlake sediment data from central Turkey. The Holocene 11: 721-736.

639 Rohling EJ (2016) Of lakes and fields: A framework for reconciling palaeoclimatic 640 drought inferences with archaeological impacts. Journal of Archaeological Science 73: 17-24.

642

Rossignol-Strick M (1999) The Holocene climatic optimum and pollen records of sapropel 1 in the eastern Mediterranean, 9000-6000 BP. Quaternary Science Reviews 18: 515-530.

Steinman BA, Rosenmeier MF and Abbott MB (2010) The isotopic and hydrologic response of small, close-basin lakes to climate forcing from predictive models: simulations of stochastic and mean state precipitation variations. Limnology and Oceanography 55: 2246-2261.

Stevens LR, Ito E, Schwalb A and Wright HE (2006) Timing of atmospheric precipitation in the Zagros Mountains inferred from a multi-proxy record from Lake Mirabad, Iran. Quaternary Research 66: 494-500.

Stevens LR, Wright HE and Ito E (2001) Proposed changes in seasonality of climate during the Lateglacial and Holocene at Lake Zeribar, Iran. The Holocene 11: 747755. 
655 Swann GEA (2010) A comparison of the Si/Al and Si/time wet-alkaline digestion 656 methods for measurement of biogenic silica in lake sediments. Journal of 657 Paleolimnology 44: 375-385.

658 Swann GEA and Leng MJ (2009) A review of diatom delta O-18 in palaeoceanography. 659 Quaternary Science Reviews 28: 384-398.

660 Triantaphyllou MV, Ziveri P, Gogou A, Marino G, Lykousis V, Bouloubassi I, Emeis

661 KC, Kouli K, Dimiza M, Rosell-Mele A, Papanikolaou M, Katsouras G and Nunez N (2009) Late Glacial-Holocene climate variability at the south-eastern margin of the Aegean Sea. Marine Geology 266: 182-197.

664

Turner R, Roberts N, Eastwood WJ, Jenkins E and Rosen A (2010) Fire, climate and the 665 origins of agriculture: micro-charcoal records of biomass burning during the last glacial-interglacial transition in Southwest Asia. Journal of Quaternary Science 25: $371-386$.

668

Turner R, Roberts N and Jones MD (2008) Climatic pacing of Mediterranean fire histories from lake sedimentary microcharcoal. Global and Planetary Change 63:

670 317-324.

671 Tyler JJ, Leng MJ and Sloane HJ (2007) The effects of organic removal treatment on the integrity of delta O-18 measurements from biogenic silica. Journal of Paleolimnology 37: 491-497. 
674 Vanniere B, Power MJ, Roberts N, Tinner W, Carrion J, Magny M, Bartlein P,

675 Colombaroli D, Daniau AL, Finsinger W, Gil-Romera G, Kaltenrieder P, Pini R,

676 Sadori L, Turner R, Valsecchi V and Vescovi E (2011) Circum-Mediterranean

677 fire activity and climate changes during the mid-Holocene environmental

678 transition (8500-2500 cal. BP). The Holocene 21: 53-73.

679 Weiss H, Courty M-A, Wetterstrom W, Guichard F, Senior L, Meadow R and Curnow

680 A (1993) The genesis and collapse of third millennium north Mesopotamian

$681 \quad$ civilization. Science 261: 995-1004.

682 Wick L, Lemcke G and Sturm M (2003) Evidence of Lateglacial and Holocene climatic

683 change and human impact in eastern Anatolia: high-resolution pollen, charcoal,

684 isotopic and geochemical records from the laminated sediments of Lake Van,

685 Turkey. The Holocene 13: 665-675.

686 Woldring H and Bottema S (2003) The vegetation history of East-Central Anatolia in 687 relation to Archaeology: the Eski Acigol pollen evidence compared with the Near $688 \quad$ Eastern environment. Palaeohistoria 43/44: 1-34.

689 Woodbridge J and Roberts CN (2010) Linking neo- and palaeolimnology: a case study 690 using crater lake diatoms from central Turkey. Journal of Paleolimnology 44:

$691 \quad 855-871$. 
692 Woodbridge J and Roberts CN (2011) Late Holocene climate of the Eastern 693 Mediterranean inferred from diatom analysis of annually-laminated lake 694 sediments. Quaternary Science Reviews 30: 3381-3392.

695 
696 Table 1 Sources of uncertainty associated with the correction of $\delta^{18} \mathrm{O}_{\text {diatom }}$ data used in 697 this paper.

\section{Source of uncertainty}

Magnitude of

uncertainty

Diatom isotope measurement analytical reproducibility $(1 \sigma) \quad 0.3 \%$

$\mathrm{Al}_{2} \mathrm{O}_{3}$ measurement analytical reproducibility $(1 \sigma) \quad 0.03 \%$

Variance in $\mathrm{Al}_{2} \mathrm{O}_{3}$ composition of turbidites (from $\bar{x}$ of $14.56 \%$ ) $\quad 1.6 \%$

$(1 \sigma)$

Variance in $\delta^{18} \mathrm{O}$ value of turbidites from $\bar{x}$ of $16.0 \%(1 \sigma) \quad 1.0 \%$

698

699 
700

Table 2 Lake isotope mass balance model summary

701

\begin{tabular}{|c|c|c|c|c|c|c|c|c|c|}
\hline & $\begin{array}{l}\delta 1(\%) \\
\text { Mean }\end{array}$ & Range & $\begin{array}{l}\text { Tav } \\
\left({ }^{\circ} \mathrm{C}\right) \\
\text { Mean }\end{array}$ & $\begin{array}{l}\mathrm{P}(\mathrm{mm}) \\
\text { Total }\end{array}$ & $\begin{array}{l}\delta p(\%) \\
\text { Weighted } \\
\text { Mean }\end{array}$ & $\begin{array}{l}\text { Qi average } \\
\text { (m³/month) }\end{array}$ & $\begin{array}{l}\text { Qo average } \\
\text { (m³/month) }\end{array}$ & $\begin{array}{l}\text { Volume } \\
\left(\mathrm{m}^{3}\right)\end{array}$ & $\begin{array}{l}\mathrm{P} / \mathrm{E} \\
\text { Annual } \\
\text { average }\end{array}$ \\
\hline $\begin{array}{l}\text { Modern } \\
\text { with no snow } \\
\text { with double snow }\end{array}$ & $\begin{array}{l}0.59 \\
0.71 \\
0.50\end{array}$ & $\begin{array}{l}1.06 \\
1.05 \\
1.06\end{array}$ & $\begin{array}{l}11.7 \\
11.7 \\
11.7\end{array}$ & $\begin{array}{l}356.2 \\
356.2 \\
356.2\end{array}$ & $\begin{array}{l}-9.4 \\
-8.5 \\
-10.4\end{array}$ & $\begin{array}{l}76328 \\
76328 \\
76328 \\
\end{array}$ & $\begin{array}{l}39812 \\
39812 \\
39812 \\
\end{array}$ & $\begin{array}{l}7500000 \\
7500000 \\
7500000\end{array}$ & $\begin{array}{l}0.422 \\
0.422 \\
0.422\end{array}$ \\
\hline $\begin{array}{l}\text { Mid Holocene i } \\
\text { Mid Holocene ii }\end{array}$ & $\begin{array}{l}1.06 \\
2.00 \\
2.00\end{array}$ & $\begin{array}{l}1.10 \\
1.22 \\
1.52\end{array}$ & $\begin{array}{l}11.7 \\
12.6 \\
12.6\end{array}$ & $\begin{array}{l}295.2 \\
295.2 \\
295.2\end{array}$ & $\begin{array}{l}-8.8 \\
-8.8 \\
-8.8\end{array}$ & $\begin{array}{l}71991 \\
70781 \\
70781\end{array}$ & $\begin{array}{l}32851 \\
25635 \\
25635\end{array}$ & $\begin{array}{l}7500000 \\
7500000 \\
6000000\end{array}$ & $\begin{array}{l}0.398 \\
0.391 \\
0.391\end{array}$ \\
\hline $\begin{array}{l}\text { Early Holocene } \\
\text { with modern temperatures }\end{array}$ & $\begin{array}{l}-2.81 \\
-2.81 \\
-0.57\end{array}$ & $\begin{array}{l}1.19 \\
0.99 \\
1.21\end{array}$ & $\begin{array}{l}10.7 \\
10.7 \\
11.7\end{array}$ & $\begin{array}{l}356.2 \\
356.2 \\
356.2\end{array}$ & $\begin{array}{l}-8.9 \\
-8.9 \\
-8.9\end{array}$ & $\begin{array}{l}116438 \\
116438 \\
90813\end{array}$ & $\begin{array}{l}86320 \\
86320 \\
54422\end{array}$ & $\begin{array}{l}7500000 \\
9000000 \\
7500000\end{array}$ & $\begin{array}{l}0.643 \\
0.643 \\
0.502\end{array}$ \\
\hline
\end{tabular}


Figure captions

705

706

Figure 1 Location of Nar Gölü in Turkey and lakes Zeribar and Mirabad in Iran.

707

708

Figure 2 Seasonal data from 2011-2012, showing increase in lake water $\delta^{18} \mathrm{O}(\mathrm{A})$ and

709

temperature (B) between the estimated times of year of diatom growth (i) and carbonate

710 formation (ii).

711

712 Figure $3 \delta^{18} \mathrm{O}_{\text {diatom }}$ and $\delta^{18} \mathrm{O}_{\text {carbonate }}$ data plotted against depth, with the error bars on $\delta^{18} \mathrm{O}_{\text {diatom }}$ 713 representing the combined uncertainties from Table 1 . There are no carbonate isotope data in sections where there were gaps due to coring (shown by white boxes on the lithology plot) or where there were high levels (>20\%) of dolomite (explained in detail in Dean et al., 2015b). Gaps in the diatom isotope data are due to gaps in coring or insufficient amounts of diatom

717 silica.

718

719 Figure $4(\mathrm{~A}) \delta^{18} \mathrm{O}_{\text {carbonate }}$ (with carbonate mineralogy data) and (B) $\delta^{18} \mathrm{O}_{\text {diatom, with }}(\mathrm{C})$ data

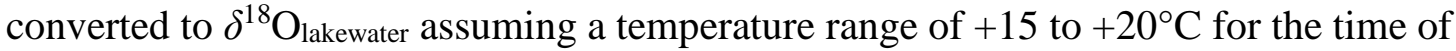

721 carbonate precipitation and +5 to $+10^{\circ} \mathrm{C}$ for the time of diatom growth. Some isotope data

722 plotted against depth are not shown against age due to issues with the chronology (discussed 723 in detail in Dean et al., 2015b). 


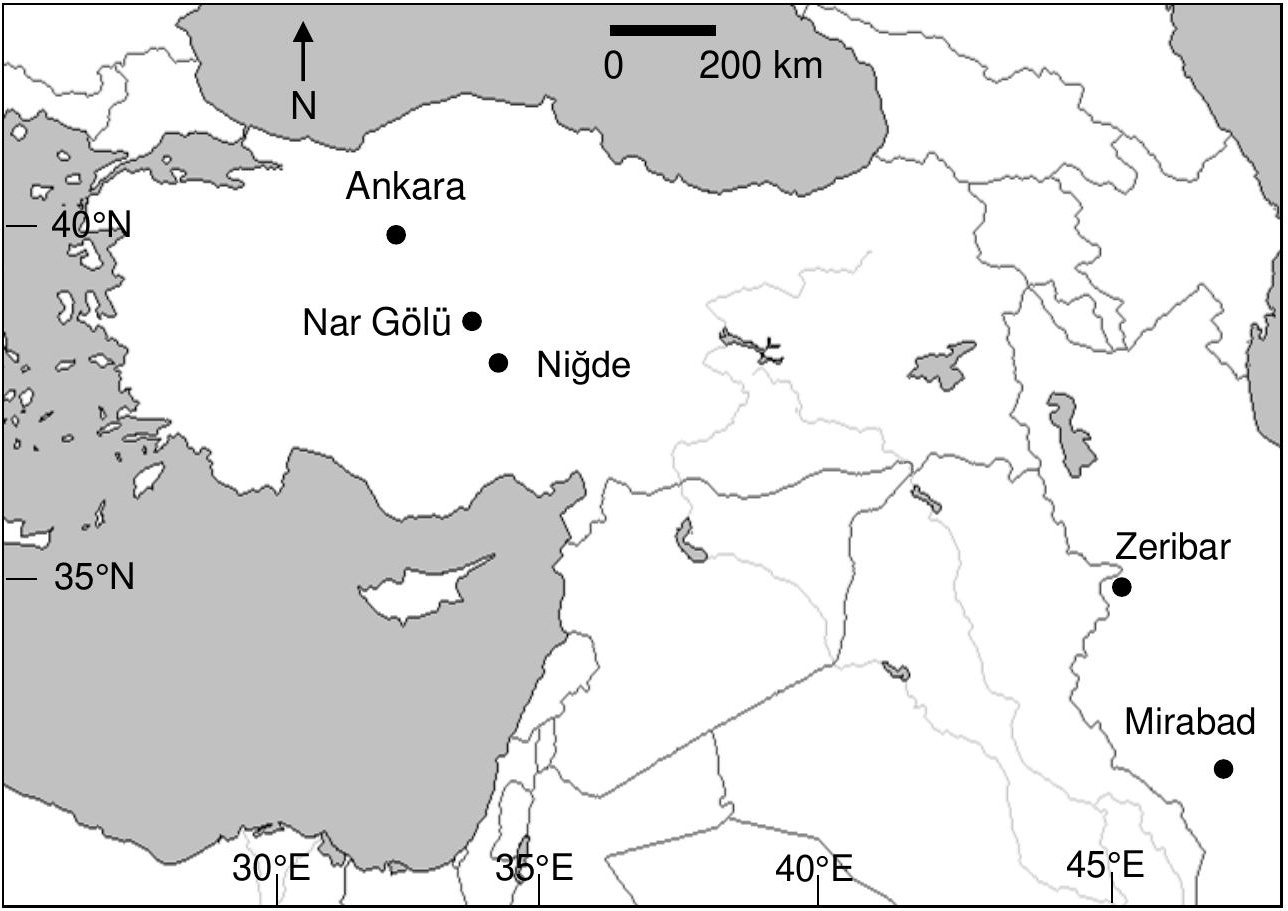




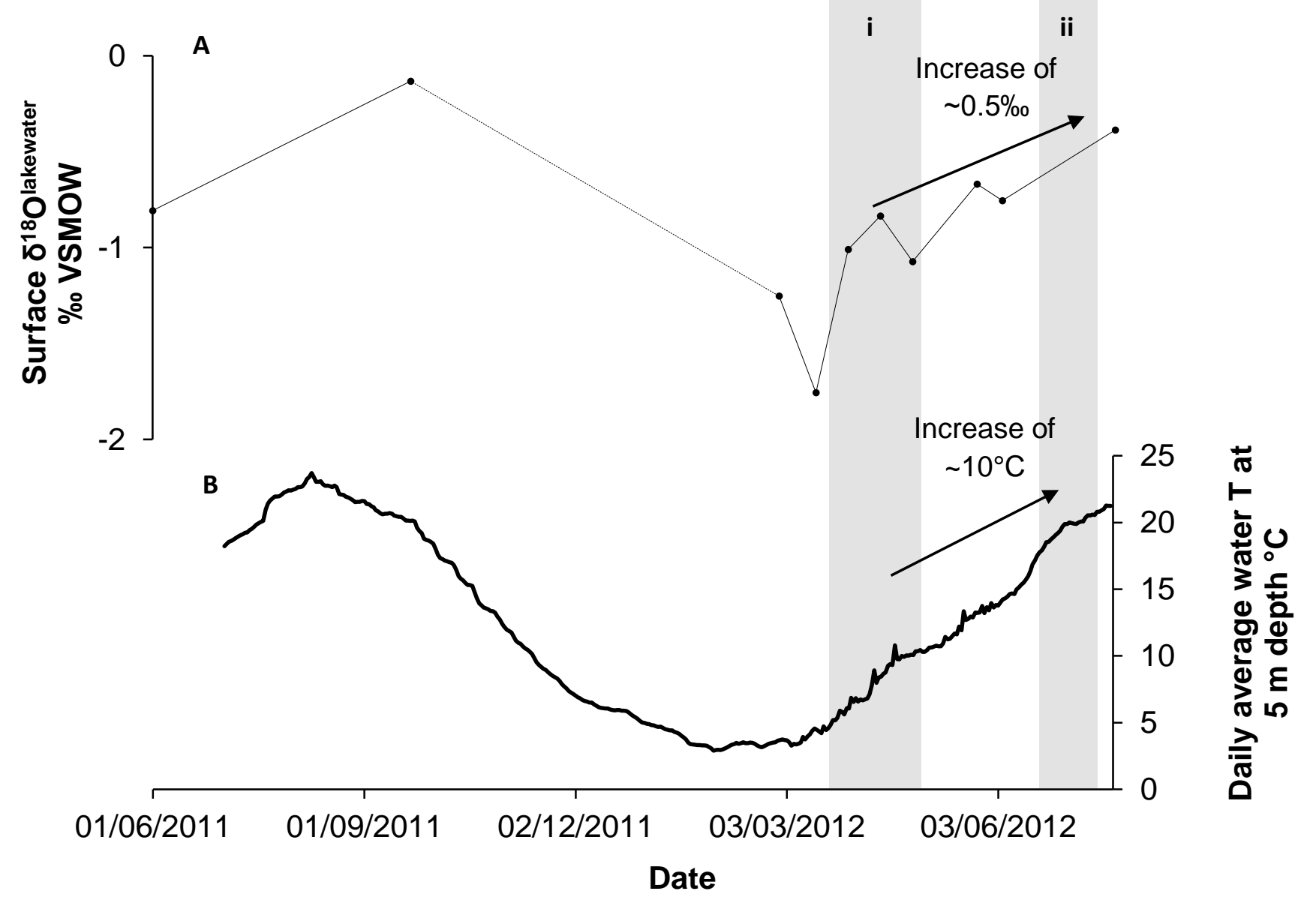




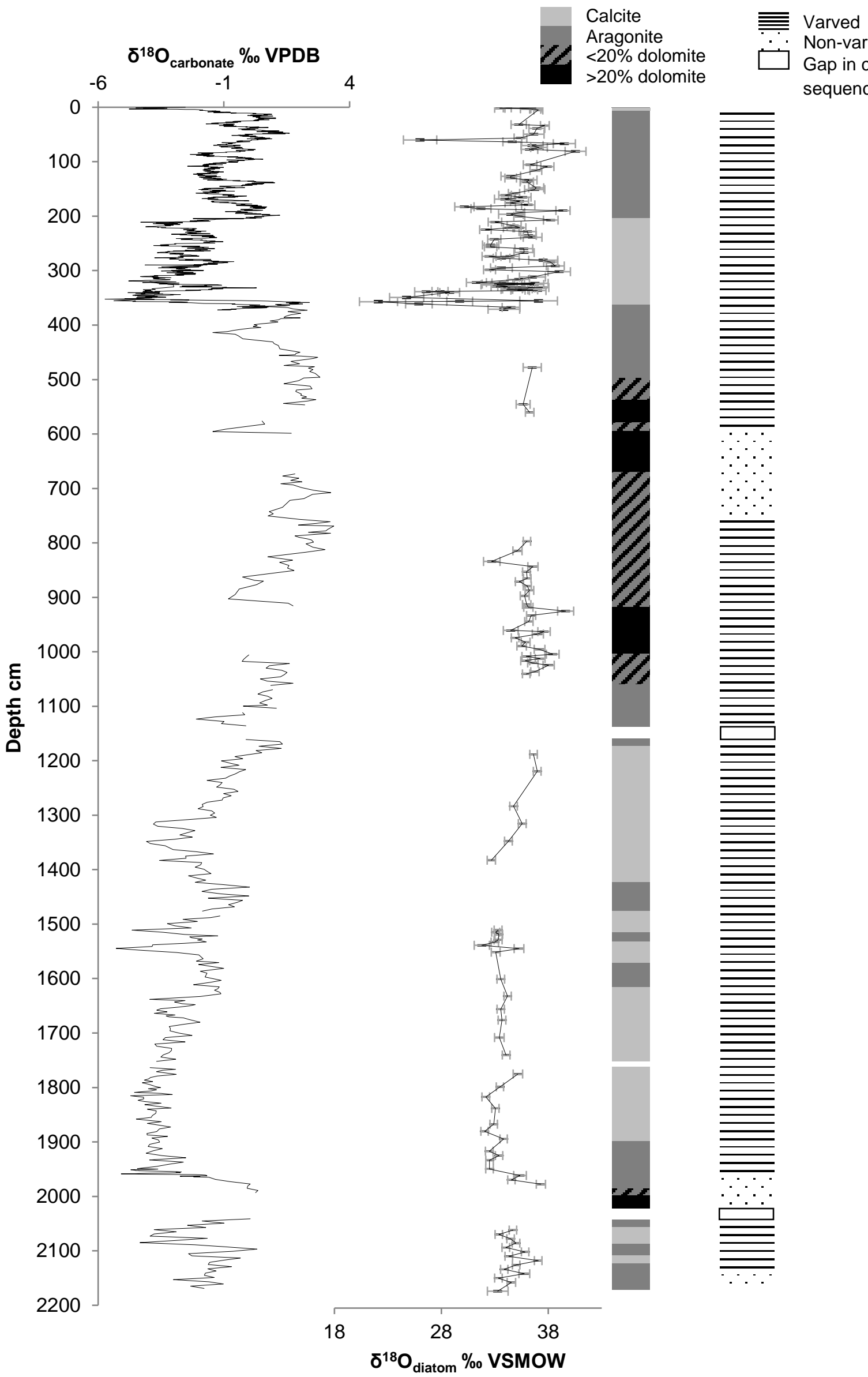




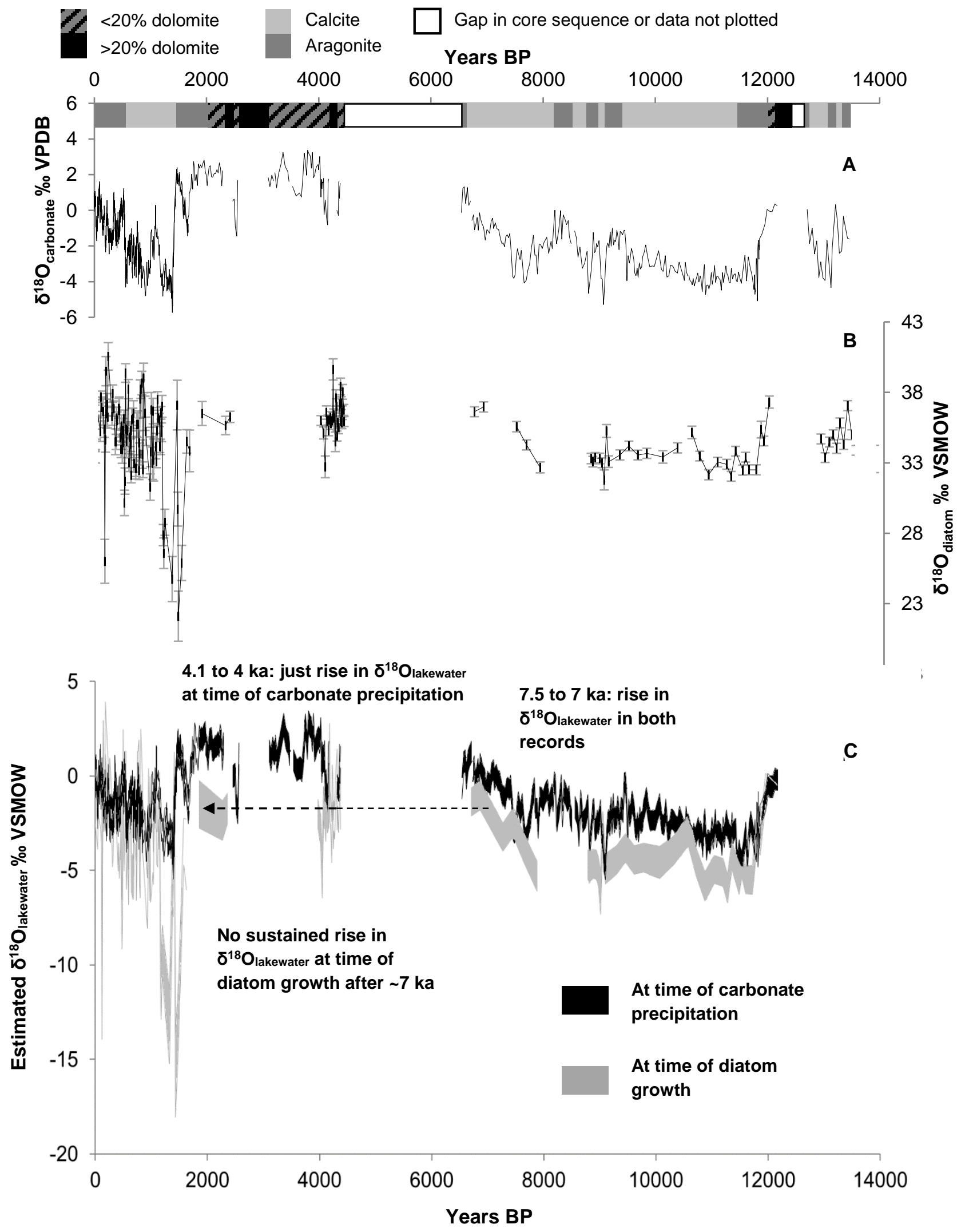


Supplementary Information for Seasonality of Holocene hydroclimate in the Eastern

Mediterranean reconstructed using the oxygen isotope composition of carbonates and

diatoms from Lake Nar, central Turkey

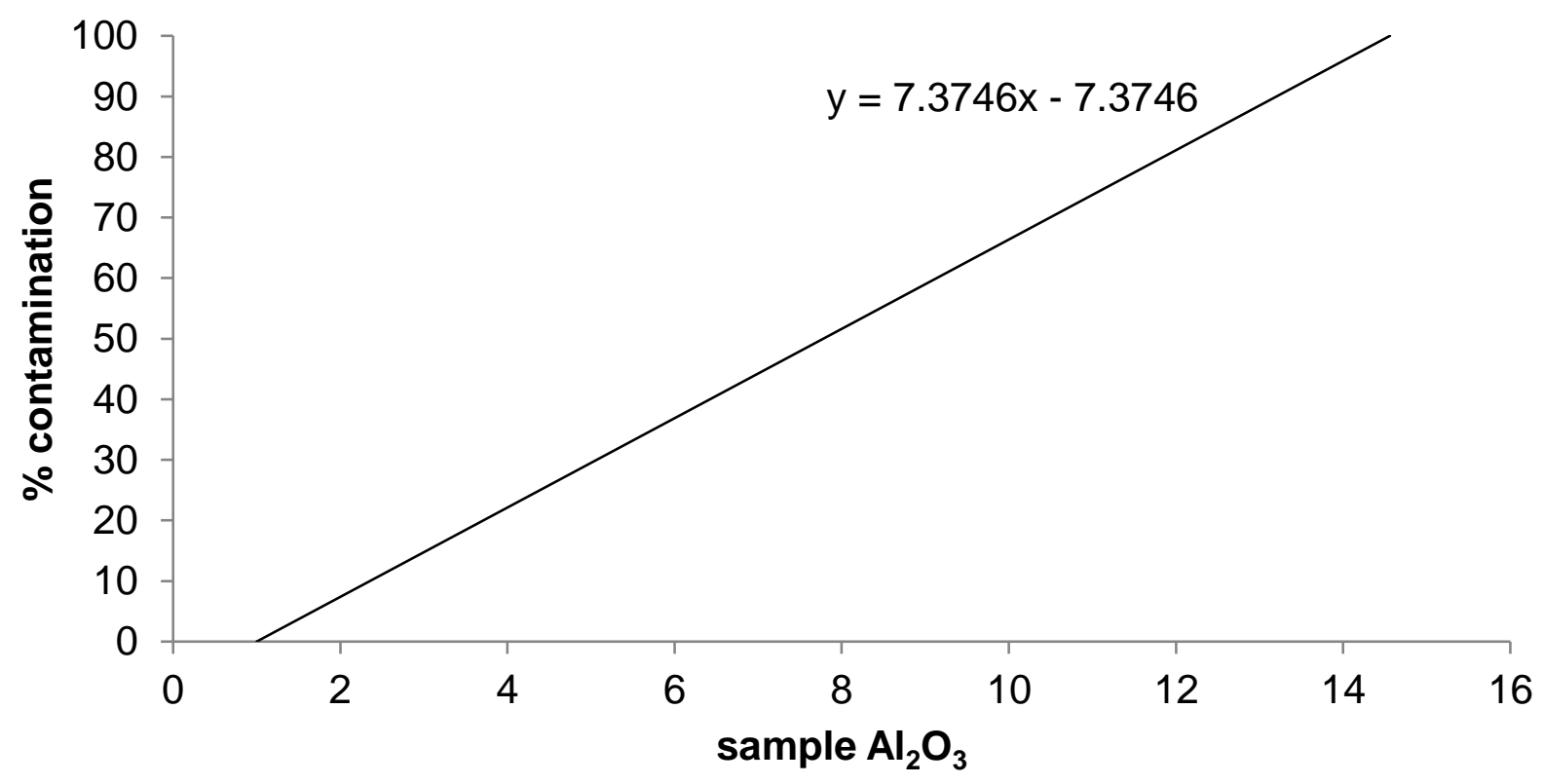

Figure SI-1 Regression line showing equation used to derive Eq. 2: a mixing line between the point when $\mathrm{Al}_{2} \mathrm{O}_{3}$ is $14.56 \%$ indicating $100 \%$ contamination and when $\mathrm{Al}_{2} \mathrm{O}_{3}$ is $1 \%$ indicating $0 \%$ contamination (i.e. $100 \%$ diatom). 


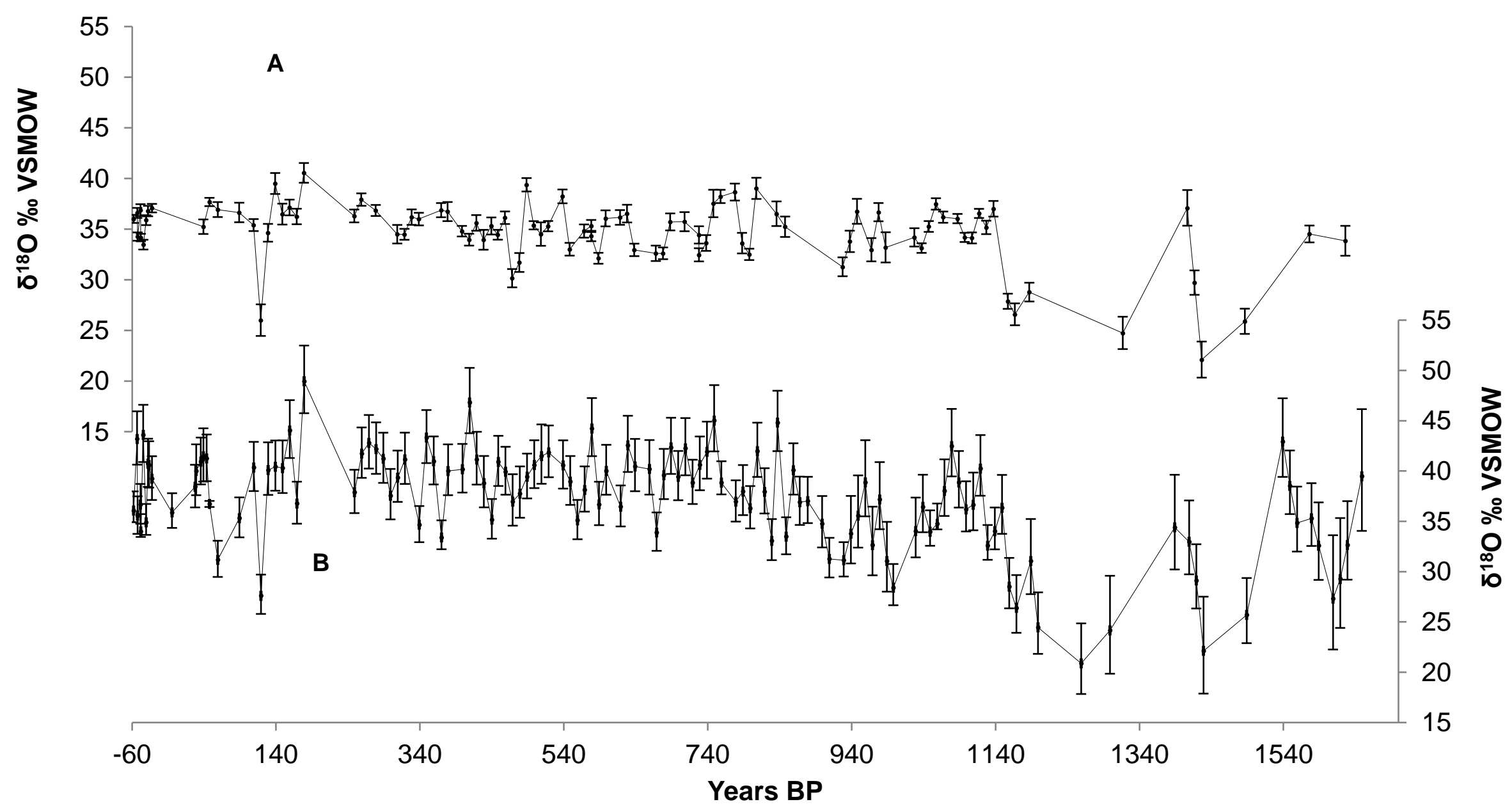

Figure SI-2 The difference between NAR01/02 diatom isotope trends in this paper (A) and as published in Dean et al. (2013) (B). Not all samples originally run and corrected in B could be included in A because many did not have sufficient material left to allow for XRF analysis. Error bars show the combined uncertainties from the factors given in Table 1. 


\section{Isotope Mass Balance Models}

\section{Theoretical model}

The following is edited from Jones et al. (2016) and Jones and Imbers (2010) for the model lake used in this study.

The water mass and isotopic mass balance of a well-mixed lake is, respectively:

$$
\begin{gathered}
\frac{d V}{d t}=P+Q i-E-Q o \\
\frac{d}{d t}\left(V \delta_{L}\right)=P \delta_{P}+Q i \delta_{P}-E \delta_{E}-Q o \delta_{L}
\end{gathered}
$$

where $V$ is the lake volume, $t$, time, $P$, precipitation on lake surface per unit time, $E$ is evaporation from lake surface per unit time and $Q_{0}$ and $Q_{i}$ are obtained as $Q_{x}=S_{x}+G_{x}$, where $S_{0}$ and $G_{0}$ and $S_{i}$ and $G_{i}$ are the surface and groundwater outflows and inflows respectively, and are measured in the same units as $P$ and $E . \delta_{P}, \delta_{E}$ and $\delta_{L}$ are the isotope values, either $\delta^{18} \mathrm{O}$ or $\delta \mathrm{D}$, of the precipitation, evaporation and lake waters respectively.

$\delta_{\mathrm{E}}$ is difficult to measure and is therefore usually calculated (e.g. Steinman et al., 2010) using equations based on the evaporation model of Craig and Gordon (1965) such that

$$
\delta_{E}=\frac{\alpha * \delta_{L}-h \delta_{A}-\epsilon}{1-h+0.001 \epsilon_{k}}
$$

where $\alpha^{*}$ is the equilibrium isotopic fractionation factor dependent on the temperature at the evaporating surface and

$$
\frac{1}{\alpha^{*}}=\exp \left(1137 T_{L}^{-2}-0.4256 T_{L}^{-1}-2.0667 \times 10^{-3}\right)
$$

for oxygen and

$\frac{1}{\alpha^{*}}=\exp \left(24844 T_{L}^{-2}-76.248 T_{L}^{-1}-52.61 \times 10^{-3}\right)$

for hydrogen. $T_{L}$ is the temperature of the lake surface water in degrees Kelvin (Majoube 1971). $h$ is the relative humidity normalised to the saturation vapour pressure at the temperature of the air 
water interface and $\varepsilon_{k}$ is the kinetic fraction factor; for $\delta^{18} \mathrm{O} \epsilon_{k}$ has been shown to approximate $14.2(1-h)$ and $12.5(1-h)$ for $\delta^{2} \mathrm{H}$ (Gonfiantini, 1986). $\delta_{A}$ is the isotopic value of the air vapour over the lake and $\varepsilon=\varepsilon^{*}+\varepsilon_{k}$ where $\varepsilon^{*}=1000\left(1-\alpha^{*}\right)$.

In the model we use an equation derived from those above to calculate the isotopic value of lake waters $\left(\delta_{\mathrm{L}}\right)$ at a given time, $t+\Delta t$, based on the value of $\delta_{\mathrm{L}}$ at time $t$, and the inputs and outputs from the lake between $t$ and $t+\Delta t$.

The left-hand side of Eq. 2 is expanded and Eq.1 substituted into it:

$$
\frac{d}{d t}\left(V \delta_{L}\right)=V \frac{d \delta_{L}}{d t}+\delta_{L} \frac{d V}{d t}=\delta_{L}(P+Q i-E-Q o)+V \frac{d \delta_{L}}{d t}
$$

and then re-written, such that $\delta_{L}$ dependences are explicit.

$\delta_{E}$ is expressed as a function of $\delta_{L}$ such that

$$
\delta_{E}=A \delta_{L}+C
$$

where, for Equation 3

$$
A=\frac{\alpha *}{1-h+0.001 \varepsilon_{k}} \text { and } C=-\frac{h \delta_{A}+\epsilon}{1-h+0.001 \varepsilon_{K}}
$$

Taking Eq. (2) and (6) and replacing $\delta_{\mathrm{E}}$ using Eq. (7):

$V \frac{d \delta_{L}}{d t}+\delta_{L}(P+Q i-E-Q o)=\delta_{P}(P+Q i)-E\left(A \delta_{L}+C\right)-Q o \delta_{L}$

Rearranging all terms in Eq.(8) then leads to:

$$
V \frac{d \delta_{L}}{d t}=\delta_{P}(P+Q i)-E C-\delta_{L}(P+Q i-E(1-A))
$$

We define $\lambda$ and $\beta$ as: $\lambda=(P+Q i) \delta_{P}-E C$ and $\beta=P+Q i-E(1-A)$ such that equation (9) can be rewritten as: 


$$
V \frac{d \delta_{L}}{d t}=\lambda-\beta \delta_{L}
$$

We assume that $\mathrm{dV} / \mathrm{dt}$ can be adequately approximated as equal to the change of volume over 1 month and all other variables are also put into the model as rates per month.

Integrating equation (10) obtains an expression for the evolution of $\delta_{L}$ with time. At this stage we introduce a first approximation by assuming a constant value for $\mathrm{V}$ for each month; consistent with constant values of $\mathrm{P}$ and Qi etc. over each month. The following parameterisation for $\mathrm{V}$ is used:

$$
\bar{V}=\frac{V_{30 t h}+V_{0}}{2}
$$

where $\mathrm{V}_{30 \text { th }}$ is the total volume on the last day of each month, and $\mathrm{V}_{0}$ is the initial volume on the first day of the month.

Integration of Eq. (10) after considering the approximation in equation (11) results in:

$$
\ln \left(\frac{\lambda-\beta \delta_{L 0}}{\lambda-\beta \delta_{L}}\right)=\frac{\beta}{\bar{V}} \Delta t
$$

Where $\delta_{L O}$ is the initial isotopic composition (i.e. at the beginning of each month) and $\Delta t=1$ for each monthly step of our model. Finally exponentials of both sides of Eq. (12) give an expression for $\delta_{L}$ :

$$
\delta_{L}=\frac{1}{\beta}\left(\lambda-\left(\lambda-\beta \delta_{L 0}\right) \exp \left(-\frac{\beta}{\bar{V}}\right)\right)
$$

\section{Values for this model}

$T_{L}$ : temperature of the lake surface water

From monitoring data of Lake Nar (Jones et al., 2005, Dean et al., 2015) and other studies (Jones et al., 2016) lake surface temperatures in the model are taken as the average of mean and maximum air temperatures. 
h: normalised relative humidity

Relative humidity values were calculated based on present day relationships with temperature (c.f. Jones et al., 2005) such that these values could change in time in palaeo scenarios.

These values were normalised to the conditions at the lake surface using the saturation vapour pressure of the air and surface water as defined in Steinman et al. (2010).

\section{E: Evaporation}

Evaporation is calculated based on the equation of Linacre (1992) that has been shown previously (Jones et al., 2005; Jones et al., 2007) to be a reasonable measure of evaporation and is especially useful for palaeo-contexts where instrumental measurements are non-existent.

$$
\mathrm{E}(\mathrm{mm} / \text { day })=\left[0.015+4 \times 10^{-4} \mathrm{~T}_{\mathrm{a}}+10^{-6} \mathrm{z}\right] \times\left[480\left(\mathrm{~T}_{\mathrm{a}}+0.006 \mathrm{z}\right) /(84-\mathrm{A})-40+2.3 \mathrm{u}\left(\mathrm{T}_{\mathrm{a}}-\mathrm{T}_{\mathrm{d}}\right)\right]
$$

where $\mathrm{T}_{\mathrm{a}}$ is air temperature $\left({ }^{\circ} \mathrm{C}\right), \mathrm{z}=$ altitude $(\mathrm{m}), \mathrm{A}=$ latitude, $\mathrm{T}_{\mathrm{d}}=$ dew point temperature $=0.52$ $\mathrm{T}_{\mathrm{a} \min }+0.60 \mathrm{~T}_{\mathrm{a} \max }-0.009\left(\mathrm{~T}_{\mathrm{a} \max }\right)^{2}-2{ }^{\circ} \mathrm{C}$.

\section{$\delta_{P:}$ isotopic composition of precipitation}

Values for the isotopic composition of rainfall at Nar came from the Online Isotopes in Precipitation Calculator (Bowen et al., 2005; Bowen, 2016).

Isotopic values of snow were based on sampling of snowfall from the catchment (Dean et al., 2013) and were fixed at $-15 \%$ (i.e. more negative than rainfall). Monthly values are kept as modern throughout, although the weighted annual mean values change as the amount of precipitation in a given month changes in each scenario (Table 2).

\section{Qi: surface and groundwater inflow}

The model lake has no surface inflow; this is similar to Lake Nar where there are no permanent stream inflows to the lake.

Monitoring of springs within the Nar catchment (Jones et al., 2005) has shown these to be meteoric water, such that the isotopic composition of inflowing waters to the model lake are considered to be the same as rainfall. 
Values of Qi and Qo are optimised in the model to allow a stable lake with mean isotope values, and intra-annual range, similar to that of Lake Nar. In this model Qi is a function of P:E.

Qo: surface and groundwater outflow

There is no surface run off from the model lake, or from Lake Nar.

The amount of groundwater outflow is optimised for the model as described above and in the model lake is dependent on P:E, as the amount of groundwater inflow will change the flow of water through the lake, and a constant for when Qi is potentially 0 such that the lake is balanced.

Table SI-1: precipitation values ( $\mathrm{mm})$ used in models

\begin{tabular}{|c|c|c|c|c|c|}
\hline Month & $\begin{array}{l}\text { Modern } \\
\text { Snow }\end{array}$ & Rainfall & Total & $\begin{array}{l}\text { Mid } \\
\text { Holocene } \\
\text { Rainfall }\end{array}$ & $\begin{array}{l}\text { Early } \\
\text { Holocene } \\
\text { Rainfall }\end{array}$ \\
\hline Jan & 17.0 & 16.2 & 33.2 & 40.0 & 51.0 \\
\hline $\mathrm{Feb}$ & 15.1 & 21.7 & 36.7 & 36.7 & 46.0 \\
\hline Mar & 7.3 & 31.1 & 38.4 & 30.0 & 40.0 \\
\hline Apr & 2.8 & 44.5 & 47.2 & 25.0 & 30.0 \\
\hline May & & 38.8 & 38.8 & 20.0 & 20.0 \\
\hline Jun & & 21.4 & 21.4 & 15.0 & 10.0 \\
\hline Jul & & 7.7 & 7.7 & 7.0 & 7.7 \\
\hline Aug & & 7.3 & 7.3 & 7.3 & 7.3 \\
\hline Sep & & 17.2 & 17.2 & 17.2 & 17.2 \\
\hline Oct & & 31.6 & 31.6 & 25.0 & 31.0 \\
\hline Nov & 6.5 & 35.3 & 41.8 & 32.0 & 45.0 \\
\hline Dec & 13.4 & 21.4 & 34.8 & 40.0 & 51.0 \\
\hline
\end{tabular}

Table SI-2: temperatures for Modern and Mid Holocene I scenarios $\left({ }^{\circ} \mathrm{C}\right)$

\begin{tabular}{l|r|r|r}
\hline Month & Average (Tav) & Minimum (Tmin) & Maximum (Tmax) \\
\hline Jan & 0.16 & -4.05 & 5.47 \\
Feb & 1.46 & -3.08 & 6.88 \\
Mar & 5.92 & 0.70 & 11.87 \\
Apr & 10.57 & 4.82 & 16.54 \\
May & 15.88 & 9.04 & 22.27 \\
Jun & 20.28 & 12.88 & 26.62 \\
Jul & 23.69 & 15.83 & 30.31 \\
Aug & 23.41 & 15.69 & 30.41 \\
Sep & 18.33 & 11.13 & 25.85 \\
Oct & 12.57 & 6.72 & 19.74 \\
Nov & 6.37 & 1.25 & 13.27 \\
Dec & 2.34 & -1.93 & 7.96 \\
\hline
\end{tabular}


Table SI-3: temperatures for Mid Holocene ii scenario $\left({ }^{\circ} \mathbf{C}\right)$

\begin{tabular}{l|r|r|r}
\hline Month & Average (Tav) & Minimum (Tmin) & Maximum (Tmax) \\
\hline Jan & 0.16 & -4.05 & 5.47 \\
Feb & 1.46 & -3.08 & 6.88 \\
Mar & 5.92 & 0.70 & 11.87 \\
Apr & 10.57 & 4.82 & 16.54 \\
May & 17.00 & 10.00 & 23.00 \\
Jun & 21.50 & 14.00 & 28.50 \\
Jul & 25.00 & 17.00 & 31.50 \\
Aug & 25.50 & 16.50 & 31.00 \\
Sep & 21.50 & 12.00 & 25.85 \\
Oct & 15.00 & 7.00 & 19.74 \\
Nov & 6.37 & 1.25 & 13.27 \\
Dec & 2.34 & -1.93 & 7.96 \\
\hline
\end{tabular}

Table SI-4: temperatures for Early Holocene ii scenario $\left({ }^{\circ} \mathbf{C}\right)$

\begin{tabular}{l|r|r|r}
\hline Month & Average (Tav) & Minimum (Tmin) & Maximum (Tmax) \\
\hline Jan & 0.16 & 0.00 & 5.47 \\
Feb & 1.46 & 0.50 & 6.88 \\
Mar & 5.92 & 0.70 & 11.87 \\
Apr & 10.57 & 4.82 & 16.54 \\
May & 15.00 & 9.04 & 21.00 \\
Jun & 18.00 & 10.00 & 25.00 \\
Jul & 20.00 & 13.00 & 28.00 \\
Aug & 20.00 & 13.00 & 28.00 \\
Sep & 17.00 & 10.00 & 25.00 \\
Oct & 12.57 & 5.00 & 18.00 \\
Nov & 6.37 & 3.00 & 12.00 \\
Dec & 2.34 & 0.00 & 7.00 \\
\hline
\end{tabular}




\section{$\underline{\text { References for supplementary information }}$}

Bowen GJ (2016) The Online Isotopes in Precipitation Calculator. Available at:

http://wateriso.utah.edu/waterisotopes/pages/data_access/oipc.html Accessed: 1 August 2016.

Bowen GJ, Wassenaar LI and Hobson KA (2005) Global application of stable hydrogen and oxygen isotopes to wildlife forensics. Oecologia 143: 337-348.

Craig H and Gordon LI (1965) Dueterium and oxygen-18 variation in the ocean and marine atmosphere. Stable Isotopes in Oceanography Studies and Paleotemperatures. Pisa: Laboratory di Geologica Nucleara.

Dean JR, Eastwood WJ, Roberts CN, Jones MD, Yigitbasioglu H, Allcock SL, Woodbridge J, Metcalfe SE and Leng MJ (2015) Tracking the hydro-climatic signal from lake to sediment: a field study from central Turkey. Journal of Hydrology 529: 608-621.

Dean JR, Jones MD, Leng MJ, Sloane HJ, Roberts CN, Woodbridge J, Swann GEA, Metcalfe SE, Eastwood WJ and Yigitbasioglu H (2013) Palaeo-seasonality of the last two millennia reconstructed from the oxygen isotope composition of carbonates and diatom silica from Nar Gölü, central Turkey. Quaternary Science Reviews 66: 35-44.

Gonfiantini R (1986) Environmental isotopes in lake studies. In: Fritz, P., Fontes, J. (eds). Handbook of Environmental Isotope Geochemistry, vol. 3. New York: Elsevier. pp. 113168.

Jones MD, Cuthbert MO, Leng MJ, McGowan S, Mariethoz G, Arrowsmith C, Sloane HJ, Humphrey KK and Cross I (2016) Comparisions of observed and modelled lake $\delta^{18} \mathrm{O}$ variability. Quaternary Science Reviews 131: 329-340.

Jones MD and Imbers J (2010) Modelling Mediterranean lake isotope variability. Global and Planetary Change 71: 193-200. 
Jones MD, Leng MJ, Roberts CN, Türkeş M and Moyeed R (2005) A coupled calibration and modelling approach to the understanding of dry-land lake oxygen isotope records. Journal of Paleolimnology 34: 391-411.

Jones MD, Roberts CN and Leng MJ (2007) Quantifying climatic change through the last glacialinterglacial transition based on lake isotope palaeohydrology from central Turkey. Quaternary Research 67: 463-473.

Linacre E (1992) Climate Data and Resources: a Reference and Guide. London: Routledge.

Majoube F (1971) Fractionnement en oxygene-18 et un deuterium entre l'eau et sa vapeur. Journal of Chemical Physics 187: 1423-1436.

Steinman BA, Rosenmeier MF, Abbott MB and Bain DJ (2010) The isotopic and hydrologic response of small, closed-basin lakes to climate forcing from predictive models: application to paleoclimate studies in the upper Columbia River basin. Limnology and Oceanography 5: 2231-2245. 